\begin{tabular}{cc|}
\hline \hline \hline & International Journal of Current Research \\
\hline & and Academic Review \\
ISSN: 2347-3215 (Online) Volume 9 Number 01 (January-2021) \\
Journal homepage: http://www.ijcrar.com
\end{tabular}

doi: https://doi.org/10.20546/ijcrar.2021.901.001

\title{
Management, Pest and Diseases of Stingless Bee (Trigona iridipennis Smith) with a Special Focus to Kerala, India
}

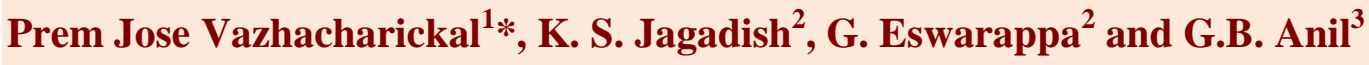 \\ ${ }^{I}$ Department of Biotechnology, Mar Augusthinose College, Ramapuram, Kerala, India-686576 \\ ${ }^{2}$ Department of Apiculture, University of Agricultural Sciences, GKVK, Bangalore, Karnataka, India-560065 \\ ${ }^{3}$ Department of Zoology, MES College, Malleswaram, Bangalore, Karnataka, India-560003 \\ *Corresponding author
}

\section{Abstract}

Stingless bees are highly social insects which populated the tropical earth 65 million years ago longer than honey bees. They are limited to tropics and subtropics lacking venom apparatus and cannot sting. Impacts of anthropogenic influences on honey bees were already reported. Recent studies also showed that the nesting behaviour of Trigona (Tetragonula) iridipennis Smith in natural habitat also vary due to interaction, pheromones and environmental stimulus. Trigona iridipennis Smith shows great diversity in plant selection for dietary as well as resin sources. The shift towards ornamental plants for foraging may be an adaptation evolved in response to human modification of the environment. The bees collect resin from a variety of sources for building nest, its maintenance and also for defence. Bee traffic is found to be related to time, season, and strength of the colony. The adult black soldier fly, H. illucens fly which thrived on decaying organic matter occasionally found entry into the stingless bee hives through the entrance tube, especially on weak colonies. The adult fly did not feed on the brood, pollen and honey pots but the larval stage of the pest damaged the colonies. The nitidulid beetle Aethina sp. damaged brood cells, pollen and honey pots. The study also highlights the various food sources of Trigona iridipennis Smith in Kerala which can be further explored for flourishing meliponiculture.
\end{abstract}

\section{Article Info}

Accepted: 08 December 2020

Available Online: 20 January 2021

\begin{tabular}{l} 
Keywords \\
\hline Tetragonula $\quad$ iridipennis; \\
Urbanization; Terrace gardens; \\
Meliponiculture; Pest and diseases.
\end{tabular}

\section{Introduction}

Honey bees dominated the earth very long before the emergence of human beings. Stingless bees have emerged much before the evolution of true honey bees (Apis cerenaindica); which is used for the mass production honey. Stingless bees evolved around 80 million years before which is estimated by calculating the age of amber trapped stingless bees discovered from New Jersey in United States. It is assumed that stingless bees first emerged in African continent and later spread across the rest of the world (Crane, 1992; Wille,
1983).Fossil record of stingless bees have been found inside pieces of amber 80 million years old (Baker and Chmielewski, 2003). These little bees developed before the continental drift. Stingless bees belong a large and diverse taxon comprising some than 60 genera (Rasmussen and Cameron, 2010). The meliponine crown clade is assumed to have approximately 80 million yeas (late Gondwanan origin). In the New World, major diversifications occurred approximately 30-40 million years ago (Rasmussen and Cameron, 2010; Biluca et al., 2016). 
Around the globe, it is estimated that there are more than 600 described species in approximately 61 genera. Approximate numbers of species so far identified are 50 in Africa, 300 species in the Americas, 60 in Asia, 10 in Australia and four in Madagascar. However, several studies over the last two decades using morphological characters (Michener 1990; Camargo and Pedro, 1992) and a single mitochondrial DNA gene fragment with limited (34 species) taxon sampling (Costa et al., 2003) resulted in phylogenies. Rasmussen and Cameron (2007) published a four-gene phylogeny of 64 meliponine taxa belonging to 22 of 25 Old World genera and 15 taxa belonging to 13 of $36 \mathrm{New}$ World genera. Around six hundred stingless bees' species are recorded and they are classified into five genera: Melipona, Trigona, Meliponula, Dectylurina and Lestrimelitta and some of them like Trigona and Melipona are the honey producing bees which are used commercially. Australian stingless (Teragonula carbonaria) bees produce less than $1 \mathrm{~kg}$ honey per year and considered as a medicine in many communities. The different species are diverse: their size ranges from $2 \mathrm{~mm}$ (the tiny sweet bees) to stingless bees slightly bigger than the European honeybee (Apis mellifera).

Even though there exist a diversity among Stingless bees behaviour, they are highly eusocial (Vazhacharickal and Jose, 2016a; Vazhacharickal and Jose, 2016b; Vazhacharickal and Jose, 2018). They belong to the tribe of Meliponini (family Apidae), and closely related to the common honeybees and found in most tropical or subtropical regions of the world.

Stingless bee species that produce honey belong to four main genus Austroplebeia, Trigona, Melipona and Tetragonisca. Austroplebeia are warm-loving species of stingless bees with cream coloured markings at the base of their thorax. It's hard to distinguish them apart from $T$. carbonaria, without looking inside at the different nest shape they have, but they often build a tunnel-like entrance into the hive, and make an intricate, lacy curtain of cerumen each night as a barrier across their doorway. The other distinguishing behavioural difference is that Trigona crawl over the intruder, into eyes, ears, mouth while the hive is being opened while Austroplebeia is non aggressive. Trigona build a hexagonal brood cell, in a flat layer spiralling outwards (horizontally) while Austroplebeia do not build in a discernable regular pattern (Gupta, 2014). The Austroplebeia queen has a light brown appearance, in contrast to the dark brown Trigona queen. There are nine species described so far viz Austroplebeia australis (Friese, 1898), A. cassiae
(Cockerell, 1910), A. cincta (Mocsáry, 1898), Austroplebeia cockerelli (Rayment, 1930), Austroplebeia essingtoni (Cockerell, 1905), Austroplebeia ornata(Rayment, 1932), Austroplebeia percincta (Cockerell, 1929), Austroplebeia symei (Rayment, 1932 , Austroplebeia websteri (Rayment, 1932).

Trigona is the largest genus of stingless bees, there are approximately 150 species presently included in the genus, in 11 subgenera. Trigona species occur throughout the Neotropical region, and also throughout the Indo-Australian region; as presently defined, with no record of occurrence in Africa. It is a genus of the Meliponini tribe which is found extensively in tropical regions which extends from Mexico to Argentina, India, Sri Lanka to Taiwan, the Solomon Islands, South Indonesia and New Guinea. Many species exists in different parts of world viz., Trigona barrocoloralensis, T. branneri, T. carbonaria, T. chanchamayoensis, $T$. collina, T. Iridipennis, T. fuscipennis, T. hockingsi, T. hyalinata, $T$. minangkabau, $T$. recursa, $T$. spinipes. Two species (Trigona binghami and Trigona minor) are newly added to the list of 30 species recorded earlier by Schwarz (1939), and Michener and Boongird (2004) making a total of 32 stingless bees of Trigona species currently recorded under two genera (Trigona and Hypotrigona) in Thailand (Gupta, 2014).

Prominent among them were Trigona apicalis Smith, $T$. melanoleuca Cockerell, T. atripes Smith, T. canifrons Smith, T. thoracica Smith, T. terminata Smith, T. ventralis Smith, T. flavibasis Cockerell, $T$. iridipennis, $T$. iridipennis, T. iridipennis, T. iridipennis, Hypotrigona scintillans, $H$. pendleburyi and $H$. klossi. The diversity of Trigona and their resin and gum collecting behaviour depended on environmental, geographical, genetical and availability of plant resources. The bees prefer to collect resin and gum from 16 plant families including Anacardiceae, Dipterocarpaceae, Euphobiaceae, Hypericaceae, Meliaceae and Moraceae. The T. apicalis collect resin and gum to make the largest number of propolis compared with the other bee species. Trigona (Tetragona) iridipennis is the most common dammar bee found all over India. Other species were reported during 1940s and 1950s in general or from some parts of the country. Besides Trigona iridipennis, three other species occur in the Khasi hills, Meghalaya (Pugh, 1947). Neto (1949) recorded a total of three species from India:Tetragona iridipennis, T. ruficornis and $T$. (Lepidotrigona) arcifera. T. ruficornis occurs in Haldwani, Uttar Pradesh (Gupta, 2014). 
Species of Trigona live in hives, and can be found in cavities in trees, mud/stone walls or underground. The various species prefer different cavity dimensions and most species have characteristic nesting sites; the nests of Trigona fulviventris most often are found at the foot of a tree. The entrance of the nest is most often very small, decorated with debris including cow dung, and other resinous materials of mainly plant origin. The small entrance protects them against other bees, phorid flies, lizards, spiders and ants. The entrance can be a tubular structure, with circular, oval or irregular shape extending into the open air. Some entrance tube opening pointing upwards while in others they point downwards. The queen is the fertile female with reproductive capacity while the workers are underdeveloped females. The workers do all the nest maintenance, bring home food, and nurse the developing bees. Males are only produced at a certain time of year and season, when new queens are produced. After mating the virgin queen (gyne) mate with males and the mated queens start their own hive with some workers near to the parent colony.

Nowadays, Trigona species considered as important pollinators for wild plants and agricultural crops especially in the tropics. They are key pollinators of macadamia, coconut, mango, and chayote. These bees also play a smaller role in pollination of coffee, avocados, and guava.

Trigona is the largest genus of stingless bees and have many subgenera, commonly known as dammar bees. These bees are quite small in size and look like mosquitoes or flies with distribution in tropics and subtropics, and even in temperate regions. They build their nests in dark enclosures like cavities in branches or trunks of trees, ant hills, termite tunnels in the ground, wall crevices or any abandoned receptacle like logs, pots and tins. The brood of Trigona, unlike those of Apis, are clusters of small uniform globular cells of wax. These pots are the cells in which the young are reared. The pots are closely stacked touching each other or separated each cell or cluster of cells being connected with others by girders or pillars of wax. Pollen and honey are stored in conspicuously large oval cells that are constructed close to the brood cell clusters or at their periphery quite apart from the with no clear separation. Due to this reason, the honey collected from dammar bees amalgamate with pollen that gets into it from pollen pots interspersed among the honey pots which affect the shelf life due to fermentation. Honey yields from dammar bees are very low; often a few grams to some $500 \mathrm{~g}$. however, from forest areas up to $2 \mathrm{~kg}$ of honey are collected from each nest of well grown colonies. The honey yield is determined various factors especially climate, foraging plants, geographic locations, colony strength and the genetic makeup of the bees. Stingless bee honey looks dark amber in colour, shows highly positive polarization. The peculiar chemical composition and physical properties of the honey are attributed to the characteristic floral range where stingless bee forages.

Stingless bees are not active all year round; they are less active in cooler weather/rainy seasons. Unlike other eusocial bees, they do not sting but will defend by biting and making irritations by entering in sensitive parts of the enemies, if their nest is disturbed. Most of them make nests in hollow trunks, tree branches, underground cavities, or rock crevices or even adapted to various anthropogenic habitats (Vazhacharickal and Jose, 2016a; Vazhacharickal and Jose, 2016b; Vazhacharickal and Jose, 2018) (Table 1-11).

\section{Stingless bees (Trigona iridipennis)}

Usually stingless bees were seen in building foundations, mud walls, stone walls and tree cervices. They prefer tropical climate. Also seen in tropical places especially Mexico to Argentina and Indo-Australian regions especially India, Sri Lanka and Taiwan (Sakagami, 1982; Wille et al., 1983).

The most prominent stingless bees seen in India is Trigona iridipennis species (Swaminathan, 2000). Before, they were known as Melipona iridipennis. Now the species located in India and Sri Lanka belong to Trigona genus and this classification is widely accepted (Michener, 1974; Sakagami, 1978). These bees got the name Trigona iridipennis due to triangular abdomen and iridescent wings. For building nest, they collect resins from trees which make them called as Dammer bees. In India especially villages and among tribal people of Kerala, stingless bees were domesticated but not much importance and attention were for the management of these bees. Much importance are given to the large scale production of Apis indica and Apis mellifera in Kerala. Very little scientific studies were conducted in stingless bees in Kerala. Stingless bees were much far ahead of medicinal properties of honey, and plant pollination when compared to other honey bees (Garedew et al., 2004). Even though the stingless bee produce less quantity of honey $(400-600 \mathrm{ml})$, due to high medicinal property of their honey, smooth taste and fragrance make them superior than other types of honey. The importance of stingless bee pollination is much higher than the value 
of their honey produced. There are lot of small plant that depend only on stingless bees for their pollination (Heard, 1999). The body of the stingless bees were designed to collect pollen and nectar from very small flowers. The stingless bee travel only around $800 \mathrm{~m}$ radius for collecting pollen and nectar which make them suitable for controlled pollination. Stingless bees could be effectively used for green houses, poly houses and controlled farming techniques. The small bees do not get much appreciation and preferences for their valuable services. For house yard honey culture these small bees could be effectively utilized due to their special features and biodiversity in Kerala.

\section{Taxonomical classification (Stingless bees)}

Kingdom: Animalia

Class: Insecta

Subclass: Dileniidae

Order: Hymenoptera

Family: Apidae

Genus: Trigona

Species: Trigona iridipennis

\section{Origin of meliponiculture}

Ancient Mayan people kept stingless bees and considered as an integral part of social and religious life. At that time also, it provide a small scale economy by providing honey, wax and resins. The cultural importance of a single central species, called Xunan-Kab (Melipona beecheii), was recorded in documents written with ideograms by the Maya, recorded in their codices. Only three of these codices have survived and one, the Tro Codex, contains most data on bees and their meaning to society. The honey produced by Xunan-Kab was considered sacred by the Maya and was also traded. Lopes de Gomara (1552) wrote that stingless bee honey occurred in different colors, flavours, and texture, and indicated that it was an important medicinal product and used to pay taxes to the Aztecs, and Inca (Roubik, 2000; Cortopassi-Laurino et al., 2006).

In Mexico honey god is there and honey as well as cerumen used in religious ceremony and offering to God. In the modern society despite of cultural changes, the stingless bees, especially the Xunan-Kab, possess a widely acknowledged status as a cultural, ecological and economic icon. However, beekeeping with stingless bees has sharply declined in the last half century which may due to popularization of other honey bees or the low honey yield of stingless bees (Cortopassi-Laurino et al., 2006).

In Brazil, stingless bees play an important role in the ethnobiology of the Kayapó (Posey and Camargo, 1985; Camargo and Posey, 1990). Thirty-four species of stingless bees, of which 9 were considered managed or semi-domesticated. Resin and cerumen were used in their artifacts and as medicine. Kayapo tribe people knows much information about bee behaviour, distribution, nest types and ecological zones. All knowledge on bees was passed orally through generations. The traditional way of finding nests by the noise made by worker bees during nest ventilation is still a method used by many native people from different communities in Eastern Amazon (Cortopassi-Laurino et al., 2006).

The Kayapó exploit stingless bee nests, when they open natural nests to collect food, some brood, pollen and honey is left for the spirit "Bepkororoti" and this allows recovery of the colony. The Kayapó seem to be aware of the role of stingless bees as crop pollinators (Slaa et al., 2006); they tend to plant bee plants near their crops to attract the bees (Cortopassi-Laurino et al., 2006).

In Africa, Byarugaba (2004) discussed the Abayandas pygmy indigenous knowledge on stingless bees in the Bwindi forest reserve, Uganda. Due to special nature of the forest, the species diversity is higher when compared to other parts. These tribal use honey as medicine especially to alleviate constipation. India collection of stingless bee honey from the forest is a part of tribal people. The stingless bee honey is an integral part of Indian Ayurverdic and folk medicine preparations. In Kerala, traditional small scale rearing of stingless bees in mud pots exist many centuries before.

\section{Regional accounts of meliponiculture}

\section{Meliponiculture in Asia}

Stingless bees far exceed honey bees in diversity and distribution. Out of more than 500 species described worldwide about 50 species occur in Asia. Southeast Asia has several honey bee species and about 45 stingless bee species. Thailand, like Viet Nam, is a very long country, extending for over $1000 \mathrm{~km}$ south to north. In the south, there are five Apis species and at least 30 stingless bee species, while in the north, there are four Apis and less than 10 stingless bee species. The southern Thai name formeliponines is "Oong", while in the north, 
they are called "Channa Long". The local people only use stingless bee honey for "medicinal purposes". Stingless bee beekeeping for pollination service is only now beginning to take root in southern Asia (in India) and in SE Asia (Malaysia and the Philippines).

In contrast to the Asian honey bee (Apis cerana), stingless bee colonies are typically long-lived (Roubik, 2006; Quezada-Euán, 2018) and have low absconding behavior. Some species of stingless bee continuously occupy the original nest, and the nest lives more than 20 years. These aspects of their biology make stingless bee species successful in meliponiculture in Southeast Asia, including Thailand. At least six of Thailand's native species have had nests successfully transferred into a wood box to pollinate orchard crops. Two species (Geniotrigona thoracica and Tetragonula pagdeni) have been used for honey production. Additionally, management costs have been lower than in apiculture. The meliponiculture might be useful to improve household income in the countryside of Southeast Asia, where there is a very high diversity of flora (Eltz et al., 2002; Kajobe and Roubik, 2006).

There are several methods for transferring stingless bee colonies from their natural habitat to artificial hive boxes - This is one of the most important features of meliponiculture. In Southeast Asia, there are several models and sizes of commercial hive boxes available for stingless bees. However, two basic models of boxes, vertical and horizontal, are used depending on the species' arrangement of brood and food pots. For vertical boxes, the brood cluster is usually placed in the bottom section of the boxes, with honey and pollen pots built on the top of the hive. For instance, a vertical commercial hive box has successfully kept a nest of Geniotrigona thoracica. This type of hive box is easy to manage and harvest the honey.

Horizontal boxes are the more popular for the small stingless bee species. The horizontal model is normally used for species that build the honey and pollen pots next to the brood clusters, such as Tetragonula pagdeni and Tetragonula fuscobalteata.

\section{Stingless bees in Indian sub-continent}

The species of stingless bees are known from the Indian subcontinent: Lepidotrigona arciferal (Cockerell), Lisotrigona cacciae (Nurse), Lisotrigona mohandasi Jobiraj and Narendran, Tetragonula aff. laeviceps (Smith), Tetragonula bengalensis (Cameron), Tetragonul
agressitti(Sakagami), Tetragonula iridipennis (Smith), Tetragonula praeterita (Walker), and Tetragonula ruficornis (Smith). Lectotypes are newly designated for T. bengalensis and T. ruficornis (Rasmuseen, 2013).

\section{Meliponiculture in India}

India is blessed with at least three native species of honey bees namely, Apis dorsata, A. florea and A. cerana and one exotic species i.e. A. mellifera. A stingless bee, Trigona iridipennis (Tetragonula sp.) also occurs throughout India. In India only one species (Trigona iridipennis Smith) of stingless bee is reported. The knowledge available on the bioecology of this species is also limited.

Stingless bees are widely known in the Indian subcontinent as "dammer bees" or "dammar bees" (dammar $=$ resin formed among dipterocarp trees). Many local names are applied with reference to the pattern of storage of pollen and honey as "Cherutheneecha" and "Arakki" in Kerala. "Tenetigalu" in Andhra Pradesh; and "Mulijenu" (Kodagu), "Mujanatejenu", "Misrijenu", "Nasarujenu", "Kirujenu" in Karnataka (Nair, 2003).

\section{Nesting habitats of Trigona iridipennis in India}

A diverse range of nesting habitats was chosen by Trigonaspp. (Tetragonulaspp.) corresponding to the equally varied climatic and geographic conditions prevailing in the southern regions of India. Because, nests were detected at different ecological zones involving tropical evergreen, semi evergreen, grassland, moist deciduous, dry deciduous, shrub lands, freshwater wetland, subtropical secondary scrub, grassy slopes and thorny scrub type of forest vegetation.

T. iridipennis is a gentle species and it can be manipulated with ease. The species found in Karnataka (Biesmeijer, 1993) Kerala (Raakhee, 2000; Devanesan et al., 2017) and Tamil Nadu (Swaminathan, 2000) have been reported as $T$. iridipennis. In Kerala stingless bees are reared as backyard beekeeping practice mainly for honey production. They are kept in wooden box, mud pots, bamboo hollows or coconut shells.

The stingless bees are hardy and easy to handle. The nests are constructed using wax in a mixture with resins, mud, faeces, or other materials collected by the bees. The nest has one entrance tube made of cerumen. The entrance of the nest may be a simple hole, often extended from the nest as an external tube. 


\section{Different types of nests}

\section{Bamboo nodes}

Two or three node length of bamboo is cut out and then split open through the centre and remove the internodes in between except the internodes at both ends (Figure 1). Colonies of stingless bees with brood, honey and pollen are transferred into the bamboo poles. A small opening is made at one end for the bees to move in and out. Using stingless bee resin all the openings other than entrance can be sealed. Using resin a ring can made and fix around the entrance, which will help the bees in finding the door to the new nest. At sunset when the bees have all entered the nest, the bamboo pole may safely place so that it is protected from direct sun-light and rain.

\section{Earthen pot}

At the side of the pot, an entrance is made with the help of a screw-driver for the bees to move in and out. Honey, pollen, brood and bees should be transferred into the pot and then a wooden plank may be used to cover the mouth of the pot. The crevices between the pot and the plank should be sealed up with resin. The pot is to be then hung down in a swing away from the direct sun light or rain (Figure 2 and 3).

\section{Wooden box}

The most widely used and most convenient nest for stingless bee is wooden box. Though boxes of different sizes and shapes are in use, it is boxes of $10 \mathrm{~cm} \times 10 \mathrm{~cm}$ $x 36 \mathrm{~cm}$ are ones that is widely used. Any hard wood can be used for the box. All openings except the entrance are to be sealed off with resin. If the boxes are built in such a way that the planks at the bottom and the top are removable; it will be convenient for honey extraction (Figure 3).

\section{Earthen bowl}

It is possible to rear stingless bees in earthen bowls having the size of big coconut shells. There are to be two bowls, arranged one above the other. The lower one should be used for depositing the brood and the bees with queen, and the upper bowl bear food pots is to be closed with a wooden plank. All openings are to be sealed with resin. An entrance with a resin lip should be arranged on the lower bowl. The upperbowl should contain an opening having $2 \mathrm{~cm}$ diameter for bee passage. As per the availability of honey any number of bowls with a hole at the bottom might be piled up. The new bowls thus added are to be placed in the middle (Figure 3).

\section{Coconut shell}

We can rear stingless bees inside big coconut shells that are split at the middle (Figure 3). Such bottom shells is to be used the same way as in the case of earthen bowls where the brood is to be deposited. The upper shell where the eye is opened may now used to cover the bottom shell. This mechanism is to be duplicated with the eye of the shell turned downward, so that the eyes of both the shells touch each other. Inside this shell we may again place pollen, honey etc. and then it is to be closed with other shell of the coconut. All openings are to be sealed off with resin. An entrance hole with a lip is to be arranged on the bottom shell at the centre. During the season of honey flow, the shells of yet another coconut with holes on both ends are to be fitted in the middle of the two sets of shells that were arranged earlier. The holes on the shells are to come in the same line.

\section{PVC pipe}

Split a 4 inch PVC pipe through the centre using a cutter and transfer a colony of stingless bee with brood and food pots (Figure 3). Both ends of the pipe can be closed using end caps or coconut shells (Figure 3). Make an opening at one end for bee passage. Seal all the openings except entrance with resin and keep the nest at perfect cool shade.

\section{Pest and diseases of $T$. iridipennis}

Threats paved way for declining stingless bees especially in South India. Although stingless bees provide good quality honey with medicinal properties and efficient pollinator, the native population is diminishing. The major causes for the decline includes extensive use of pesticides, destruction of nesting site and natural habitats, deforestation, industrialization and urbanization.

\section{Pests}

A dipteran fly Hermetia illucens L. which thrived on decaying organic matter was newly identified as a pest of stingless bee $T$. iridipennis in Kerala. Both the maggots and adults were observed from within the stingless bee hives (Nisha, 2002). All India Coordinated Research 
Project (AICRP) 2004 also reported the dipteran fly $H$. illucens as a pest of stingless bees in Kerala.

Simoes et al., (1980) described Mealonctia sinistia Borgmeier as an endoparasitic phorid fly of Nannatrigona (Scaptotrigona) postica Latreille in Brazil. Sommeijer (1999) reported phorid fly (Pseudohypocerrspo sp.) as a major pest of stingless bee in America, which fed on pollen and brood. The maggots and adults of the phorid fly Megaselia scalaris Loew affected the nested colonies of all the five stingless bee species in Kakamega forest, Kenya (Kiatoko, 2012).

Studies conducted at the Kakamega forest, Kenya showed that the brood of Meliponula bocandei Cockerell, Meliponula ferruginea Cockerell (reddish brown), Meliponula ferruginea Cockerell (black), Meliponula lendliana Friese and Hypotrigona gribodoi Magretti stingless bee species were vulnerable to invasion by A. tumida grubs (Kiatoko, 2012). He also reported other coleopteran pests like Rhizoplatys mucronatus Beauvois and Tenebroides mauritanicus Linnaeus from the pollen pots of feral colonies of $M$. bocandei and $M$. ferruginea from Kakamega forests, Kenya.

It was asserted by Flechtmann and Camargo (1974) that a small whitish mite Neotydeolus therapeutikos was found in the nests of Trigona postica Latreille in Brazil. Meliponopus palpifer G.N. a phoretic deutonymph (hypophus) was noticed in Melipona seminigra Merrillae from Brazil (Fain and Fletchmann, 1985). Neocypholaelaps phooni Baker a new species of mite found in nests of stingless bees in Malaysia was reported by Baker and Delfinado (1985). Delfinado-Baker and Baker (1988) observed the incidence of two mites belonging to the genus Eumellipites in the nests of Tetragonula (Trigona). A new species of mite Neocypholaelaps malayensis Pilsbry found in the nests of Trigona itama Cockerell and $T$. iridipennis in Malaysia was described by Delfinado et al., (1989). Hallim and Sommeijer (1994) reported robber bees Lestrimelitto $s p$. as a major pest of Melipona trinitatis Cockerell. Smiley et al., (1996) reported a new species of mite Hypoaspis (Mesostigmata: Laelapidae), as a pest of stingless bee T. iridipennis from Malaysia.

Nisha (2002) reported a mite Amblyseius infestation in bamboo hives of stingless bees in Kerala. New species of mite, Carpoglyphus lactis L. was reported by Vijayakumar et al., (2013) from the nests of $T$. iridipennis in Tamil Nadu.

\section{Insect predators}

The females of the assassin bug Apiomerus pillipes Santschi (Reduviidae, Harpactorinae) were predators of the genus Melipona (Vijayakumar et al., 2012; Silva and Gl-Santana, 2004) in Brazil. Wattena and Jongjitvimol (2007) reported that Pahabengkakia piliceps Miller (Assassin bug) (Hemiptera: Reduviidae: Harpactorinae) as a predator of the stingless bee Trigona collina Smith in Thailand. The Acanthaspis siva Distant (Reduviidae: Hemiptera) was reported as a predator of stingless bees and honey bees in Kerala (Premila et al., 2013; Divya et al., 2016).

Ants (Figure 4, 5) belonging to subfamilies of Dorylinae and Ecitoninae, which included the army ants, were fearsome predators of honey bees and stingless bees (Hamida, 1999). Raakhee (2000) observed Solenopsis geminata Wheeler (ants) entering the weak colonies of stingless bee hives to rob pollen stock from colonies in different locations of Kerala. Ants ( $S$. geminata) were seen entering the hive especially in initial stages when the colonies were just divided (Devanesanet al., 2017). The ant Myrmicaria sp. as a predator of stingless bee species in Kenya was reported by Kiatoko (2012).

George (1934) reported a wasp, Megachile spp. which visited the nest and snatched wax from the entrance of $T$. iridipennis. A species of wasp Megachile disjuncta Fabricius was observed as a predator of T. iridipennis in Kerala (Nisha, 2002). A wasp, Philanthus sp. (Hymenoptera: Crabronidae) which was also referred to as bee wolf was observed as a major predator of $M$. ferruginea (black) in Kenya (Kiatoko, 2012).The centipede Scolopendra hardwicki Newport (Chilopoda) was a specialized predator of stingless bee $T$. iridipennis in Tamil Nadu (Vijayakumar et al., 2012).

\section{Spider predators}

Spiders (Figure 6) are major predators of stingless bees. Craig et al., (1996) reported that Nephila clavipes L., a large orb spinning spider feeds on Trigona fluviventris Friese by making large yellow webs. T. fluviventris is attracted to yellow colour and hence they are trapped in the webs of $N$. clavipes more frequently than in any other spider web. Wattena and Jongjitvimol (2007) reported that Nephila maculate F. a golden orb web spider and Argiope sp. a golden garden spider were predators of Trigona collina Smith nests in Thailand. Different species of spiders (Thomisus spp.) were found to predate on stingless bees in Kerala (Devanesan et al., 2017). 
Large animals like civets (Paradoxurus hermaphrodites Pallas), bears (Melursus ursinus Shaw), honey badgers (Mellivora capensis Storr), tamandus (Tamandua tetradactyla Linnaeus), tayras (Eira barbara Linnaeus) and chimpanzees (Pan troglodytes Blumenbach) were also reported as important enemies of stingless bees (Roubik, 1989).

The African blue fly catcher bird, Elminia longicauda teresita Antinori was reported as a major hunter of forager stingless bees, M. ferruginea (black) and $M$. ferruginea (reddish brown) by Kiatoko (2012) in Kenya.

The stingless bee $M$. lendliana was one of the predators that frequently robbed propolis from $M$. bocande $i$ hives which were put in place to seal gaps in their hives (Kiatoko, 2012). He also reported that the honey bee A. mellifera robbed the honey stored in pots in the nests of the five stingless bees at the Kakamega forest in Kenya.

\section{Diseases}

Anderson and Gibbs (1988) reported that Trigona pupae were infected by Kashmir bee virus. Five Bacillus species have been reported as being associated with stingless bee colonies of Trigona hypogea Silvestri (Zulkhairi Amin et al., 2020). A type of yeast was found to infect the hives of three species of stingless bees $M$. ferruginea (reddish brown), M. ferruginea (black) and M. lendliana in Kenya (Kiatoko, 2012).

\section{Assessment of damage and yield loss}

The assessment of disease can be estimated by damage on brood cells, pollen pots, honey pots, number of bees and strength of the colony.

\section{Extent of damage by pest, predators and diseases Insect pests}

The larvae of dipteran fly, $H$. illucens massively fed on the pollen, honey, brood and cerumen deposits of $T$. iridipennis (Nisha, 2002). The impact of infestation of $A$. tumida was severe as it resulted in rotting of the nests, which dried up over time. Adult bees were also found to be affected by the infestation as the bees abandon the severely infested hives (Kiatoko, 2012).

The larvae of coleopterans such as Cetonia apaca L. and Cetonia morio L. belonging to the family Cetonidae were reported to harm stingless bees by entering the hives to feed on honey and dig galleries in to the wax (Leonard,
1983). The commercial honey production was severely affected in parts of North Africa when there were massive invasions of coleopteran beetle (Hamida, 1999).

Nisha (2002) reported a mite Amblyseius sp. feeding on the pollen leading to the destruction of the entire colony. C. lactis mites were found to infest the pollen store initially and subsequently spread over the brood cells (Vijayakumar et al., 2013).

\section{Insect predators}

The nymphs of assassin bug P. piliceps occupied the nest entrance and killed the forager bees. The nymphs and adults of $P$. piliceps captured, immobilized and fed on the prey. Bugs used their legs to capture and immobilize returning foragers. They used their rostrum (beak) to pierce the thorax and abdomen or mesoscutellum of their prey in order to access the haemolymph (Wattena and Jongjitvimol, 2007). Premila et al., (2013) reported that the nymphs of the reduviid predator, A. siva preyed upon the adults of stingless bees by camouflaging themselves by attaching bits of debris over the body. The bugs fed on the adult workers of Apis and stingless bees by sucking body fluid.

Hamida (1999) reported that ants can be a major predator of honey bees and stingless bees in many ways. Ants belonging to sub families of Dorylinae and Ecitoninae, which includes the army ants are fearsome predators of honey bees and can destroy a whole apiary within a few hours. Unlike other ants they do not prefer honey or pollen; instead they prey on adults, larvae and eggs of honey bees. The ant, Myrmicaria sp. was found to capture the stingless bee species in the newly nested hives where the gaps were not obtruded completely (Kiatoko, 2012).

The wasp, Philanthus sp. (Bee wolf) hunt forager bees flying out and returning into their hives by hovering diagonally closer (up to $7 \mathrm{~cm}$ ) to the nest entrance of the targeted colony (Kiatoko, 2012).The centipede, $S$. hardwicki damaged the wooden hives of stingless bee colonies and regular entry of this centipede reduced the strength of worker bees (Vijayakumar et al., 2012).

\section{Spider predators}

Spiders construct their webs towards sources of abundant prey. Argiope spiders generally build their webs in stingless bee habitat especially near the ground and hollow logs where the stingless bees build their nests. 
This increases the chance of encounter with the spider web whilst foraging and returning to the hive (Rao et al., 2008). Devanesan et al., (2017) observed that Thomisus spiders were attacking the stingless bees at the hive entrance as well as from their foraging sites.

\section{Diseases}

The pillars and involucrums which were the main components in a stingless bee nest were vulnerable to infestation by a type of yeast in three species of stingless bees $M$. ferruginea (reddish brown), M. ferruginea (black) and $M$. lendliana. The yeast was reported to infect 20.70 per cent of the nested colonies of $M$. ferruginea (black), 20.20 per cent of the nested colonies of $M$. ferruginea (reddish brown) and 33.30 per cent of the established colonies of M. lendliana. Up to 16.70 per cent of the infected nests of $M$. ferruginea (black) and 17.60 per cent of the infected nests of $M$. ferruginea (reddish brown) and 33.30 per cent of $M$. lendliana absconded due to this infection (Kiatoko, 2012).

\section{Pesticide usage and poisoning}

Stingless bees are required for the pollination of many ornamental and food crops. Due to severe pest and improve crop productions farmers use various pesticides and insecticides to control the pest and diseases. Unfortunately many beneficial insects including honey bees are very susceptible to pesticides. The use of pesticides for pest control on one hand and role of honey bees in crop pollination on other hand become an essential component in modern agriculture (Thompson and Thorbahn, 2009; Kiljanek et al., 2016). Large number of killed honey bees is found near to hives and field due to insecticidal poisoning. Poisoning of insecticides to honey bees is more profound because of their long hours of working on the crop flowers for pollen and nectar collection (Thompson and Hunt, 1999).

\section{Documentation of the pests and diseases}

The pests recorded were dipteran fly Hermitia illucens. L from Pathanamthitta district and nitudilid beetle Aethina $s p$. from Kottayam and Idukki districts. The two predators recorded were reduviid bug Acanthaspis siva Distant and assassin bug Sycanus sp. from Thiruvananthapuram and Sycanus sp. alone from Kollam district. Eight different predatory spiders were observed. They included cream crab spider Thomisus projectus Tikader which was recorded from all the five districts but the white crab spider Thomisus lobosus Tikader was recorded from Thiruvananthapuram and Pathanamthitta. Only grey sphere spider Neoscona nautica Koch was documented from Pathanamthitta and Idukki whereas common wall jumper Menemerus bivittatus Dufour was observed from all the districts except Kollam. The common zebra jumper Plexippus paykulli Audouin was observed from Kottayam and Idukki. Two tailed spider Hersilia savignyi Lucas was recorded form Kollam and Idukki. The common house spider Heteropoda venatoria Linnaeus was recorded from Thiruvananthapuram, Pathanamthitta and Idukki. Box spider Crossopriza lyoni Blackwall was documented from all the five districts.

\section{Pests}

\section{Black Soldier Fly (Hermitia illucens)}

The adult fly was smoky black winged, measuring 15-20 mm long. Wings were held over the back when at rest. The fly was easily recognized by their two translucent spots on first abdominal segment (Figure 4). The fly thrived on decaying organic matter and occasionally found entry into the stingless bee hives through the entrance tube, especially on weak colonies. The adult fly did not feed on the brood, pollen and honey pots but only the larval stage of the pest damaged the colonies. The maggots were dull, whitish color, plump, firm and leathery with tiny yellowish black head (Figure 4). The flattened body was composed of a strongly sclerotized head capsule, three thoracic and eight abdominal segments. The pupae were enclosed in a puparium (Figure 4).

\section{Nitidulid Bettle (Aethina sp.)}

The beetle was a destructive pest of stingless bee colonies, causing damage to brood cells, pollen and honey pots. The adult beetle was dark brown and about 5 $\mathrm{mm}$ in length. Adults were broad, flattened and oval in shape. Antennae clubbed and elytra are shortened (Figure 5). The adults were found on the rear portion of the brood, pollen and honey pots of a hive. The grubs and adults of beetle were observed on the decaying hive materials. They completed their life cycle inside the damaged hives. Female beetles laid irregular masses of whitish eggs in cracks or crevices in a hive (Figure 5). The eggs hatched into white-colored grubs in 2-3 days that will grow to $10-11 \mathrm{~mm}$ length in 10-16 days (Figure 5). Grubs had three pairs of legs and dorsal spikes. The pupae were whitish in color with a length of $5 \mathrm{~mm}$ (Figure 5). 


\section{Insects predators}

\section{Reduviid bug (Acanthaspis siva)}

Adult is black or brown coloured with elongated head; distinct narrowed neck and legs were prominent and segmented. The nymphs camouflaged themselves by attaching bits of bee cadaver onto their body and remained close to the entrance tube of the colonies (Figure 5). Long stylets were present.

\section{Assassin bug (Sycanus sp.)}

Adult insects were orange or black in body colour (Figure 5). The abdomen was curved upward with a large black spot and was fully covered by wings. Bugs have stylets that were at least twice as thick as their antennae. However, the stylets were shorter, stouter and curved. The forelegs were raptorial. The adults and nymphs of Sycanus were observed around the hives, crevices and on tree trunks in the vicinity of stingless bee hives. The eggs were brown in colour and was laid in clusters and cemented to each other (Figure 5). Nymphs were wingless and reddish orange in colour (Figure 5).

\section{Spider predators}

Eight different types of predatory spiders were documented from the hive entrance of stingless bee colonies and from the flowers foraged for nectar/ pollen.

\section{Cream crab spider (Thomisus projectus)}

Cephalothorax reddish brown, as wide as long, lateral projection present at the occular region. Lateral sides slightly darker than median portion. Abdomen was typical pentagonal shape, yellowish brown (Figure 6).

\section{Grey sphere spider (Neoscona nautica)}

Cephalothorax longer than wide, blackish, cephalic region darker; thoracic region near posterior end brownish and excavated. Dorsum of abdomen was velvety black, with a mid dorsal slightly paler region with two lateral projections. A pair of whitish or greyish spots was present on the anterior half (Figure 6).

\section{Common wall jumper (Menemerus bivittatus)}

Cephalothorax "U" shaped, both cephalothorax and abdomen was brown coloured, with dull brown bands along the margins (Figure 6).

\section{Common zebra jumper (Plexippus paykulli)}

Both the cephalothorax and abdomen were dull sand yellow colour; with an inconspicuous mid-dorsal band in the cephalic region while the abdomen had a conspicuous white spot about the middle. Abdomen longer than wide, nearly oval shaped with a narrowing posterior end (Figure 6).

\section{Two tailed spider (Hersilia savignyi)}

Cephalothorax and abdomen were flat and almost circular, slightly broader than long. Abdomen greyish with a darkish lanceolate cardiac area and dark transverse margins posteriorly. Posterior lateral spinnerets are very long, much longer than the abdomen (Figure 6).

\section{Common house spider (Heteropoda venatoria)}

Cephalothorax dorsoventrally flattened and yellowish brown in colour. Abdomen elongated, oval and same in colour as that of cephalothorax. Females carry the white disc-shaped egg sac under the body with the help of palps (Figure 6).

\section{Box spider (Crossopriza lyoni)}

Cephalothorax wider than long, greyish white in colour, a dark band along mid longitudinal line and top part of the cephalothorax with deep excavation. Abdomen greyish off white with black and white patches in the sides and dorsum, triangular in shape when viewed from sides, with the spinnerets located in the lower projection of the triangle. A small conical extension was projected at the upper posterior end of the abdomen (Figure 6).

\section{Diseases of stingless bees}

The fungus was isolated from abandoned hives, pollen pots, honey pots, propolis and also from the dead bees lying inside the hive floor. Two fungal isolates of Paecilomyces variotii Bainier was isolated from Thiruvananthapuram district while a single isolate of Aspergillus niger Tiegh was isolated

\section{Paecilomyces variotii}

The fungal growth was found in abandoned hives, pollen pots, honey pots, propolis and on the walls of the hive. No dead bees were found in the hives from which $P$. variotii was isolated. Studies on the cultural characters 
on Potato Dextrose Agar (PDA) plates showed that the fungus produced pale cream coloured colonies and they reached a growth diameter of $9.0 \mathrm{~cm}$ in 14 days. The colonies appeared floccose and powdery due to dense production of conidiophores (Figure 7). The colonies get darkened as it become older. Microscopic characters of the fungal growth revealed that the conidiophores appeared in dense, vertically arranged whorls or branches. Each conidiophore bears single to many phialides, 30-100 $\mu \mathrm{m}$ in length. Phialides appeared solitary or in whorls, variable in length (10-25 x 2.0-5.0 $\mu \mathrm{m})$. It appears cylindrical at the base and tapers abruptly into a long cylindrical bottle shaped necks. Some phialides appear slightly bend towards the end. Conidia are hyaline to light yellow, smooth-walled, shape varies from subglobose to ellipsoidal, $(2.0-5.0 \times 2.0-4.0 \mu \mathrm{m}$ in length). Chlamydospores appear in old cultures, singly or in short chains globose, thick-walled, 4.0-8.0 $\mu \mathrm{m}$ in diameter.

\section{Aspergillus niger}

The fungus was isolated from dead bees lying inside the hive floor and was not found to infect or contaminate the hive or its components like brood cells, honey pot or pollen pot.The fungus produced white mycelium on PDA, covered $9.0 \mathrm{~cm}$ in 12 days (Figure 7). Conidiophores were hyaline and 500- $1000 \mu \mathrm{m}$ in length. Thus the microscopic characters showed that the fungus possessed large globose conidial head (vesicle) and was dark brown in colour (up to $75 \mu \mathrm{m}$ in length). Metulae was club shaped 5-10 $\mu \mathrm{m}$ long. Conidia were globose to subglobose 3-4 $\mu \mathrm{m}$ with rough surface.

\section{Mode of damage by pests}

\section{Black soldier fly (H. illucens)}

The maggots of the dipteran fly, H. illucens fed massively on the brood cells, pollen pots, honey pots and cerumen deposits of T. iridipennis (Figure 8).

The affected colony was completely damaged and sluggish maggots of the fly were seen entangled within a slimy mixture of pollen pots, honey pots, brood cell and cerumen. Its excreta were found inside the hive which resulted in a foul smell.

The maggots were also found to inhabit the nests abandoned by stingless bee colonies after migration. The adult flies entered such hives and deposited their eggs in it.

\section{Nitidulid beetle (Aethina sp.)}

The grubs and adults of nitidulid beetle tunnelled through pollen pot, honey pot and brood cells, feeding and defecating, causing discoloration and fermentation of the honey (Figure 8). Beetle primarily attacks weak or small colonies, causing little damage to well established colonies. More than thousand adult beetles and several hundred grubs were observed in infested hives. Apart from these, the colony was found to abscond in severely infested hives. The damaged honey was not good for human consumption.

\section{Prey capturing behaviour of insect predators of stingless bees}

\section{Reduviid Bug (A. siva)}

The adults and nymphs of A. siva was observed around the hives, crevices and on tree trunks in the vicinity of stingless bee hives. The adults of $A$. siva mostly preyed upon the worker bees that were found around the hive entrance. Both adults and nymphs preyed upon the bees by piercing its body and immobilizing them before sucking the fluid with stylet.

\section{Assassin bug (Sycanus sp.)}

The adults of Sycanus mostly preyed upon the worker bees that were found around the hive entrance while the nymphs preyed upon the forager bees when they enter or leave the hive. Feeding behavior is similar to that of $A$. siva. They often grasp their prey with their front legs, then swing their stylet up from under their bodies to insert into the bees.

Acanthaspis siva is an entomosuccivorous assassin bug (Reduviidae: Hemiptera). Body is black with wrinkles (rugulose); the deep inner layer of the skin (corium), bears basal and sub basal angular creamy spot; flattened lateral borders of the abdomen (connexivum) is spotted with pale yellow colour; basal joint of antennae is black and remaining joints are brown; posterior lobe of pronotum is rugulose and centrally marked with parallel grooves (sulcate); scutellar spine ascendant obliquely and apex of membrane is creamy white.

It is found in the tropical rain forests of southern India, underneath the loose dry barksof trees like Eucalyptus globulus, Thespesia populanea, Pithecellobium dulce, Tamarindus indicus and Hevea brasiliensis. It has been either found in groups or solitary condition. The adults 
are found with nymphs. Nymphs camouflage themselves by attaching bits of debris over the body which reduces the chance to be cannibalized by co-instars.

Both nymphs and adults of $A$. siva freely lurk around the hives, crevices or in tree trunk near the location of the bee colonies. It hunts worker bees at their nests. Observations revealed that adult bugs suck body fluid of adult worker bees of Apis cerana.

The bug approaches the prey, pierces its body and immobilises it before sucking the fluid. It is an aggressive, voracious feeder during nymphal stages and feeds on an average of $10 \mathrm{~A}$. cerana bees per day (Premila et al., 2013).

\section{Prey capturing behaviour of spider predators of stingless bees}

\section{Cream crab spider (T. projectus)}

The adult forager bees were preyed upon by $T$. projectus, found camouflaged inside the flowers, when the bees visited flowers. Mostly the female spiders were found to capture the bees.

\section{White crab spider (T. lobosus)}

Crab spiders were commonly found in flowers hiding behind sepals and petals. They do not build web instead they moved over the ground and climbed the flowers and plants in search of bees. The spider was also found to camouflage on flowers and attack the adult bees during foraging.

\section{Grey sphere spider ( $N$. nautica)}

Commonly seen in grasslands associated with water bodies and appears in the web during evening only. Foraging stingless bees were seen entangled in the web.

\section{Common wall jumper spider (M. bivittatus)}

M. bivittatus inhabits tree trunks and were seen mostly near the stingless bee feral colonies. The spider actively moved in a criss-cross pattern in search of small insects like stingless bees especially on sunny days.

Both the young and old spiders were found to feed on stingless bees which alight on nest walls. They do not build a web but instead, stalked their prey before launching an attack by leaping on the victim.

\section{Common zebra jumper spider (P.paykulli)}

Seen on walls of houses, on compound walls and tree trunks near to stingless bee hives. Males are active under sunshine. These spiders actively jump over the stingless bees in feral colonies for feeding.

\section{Two tailed spider (H. savignyi)}

It lives on the tree trunks, feeding on moths, ants and small insects like stingless bees. These type of spiders exhibit colour variation according to the substrate. They capture stingless bees mainly near the hives, though they were found mostly attacking feral colonies.

\section{Common house spider (H. venatoriai)}

Common house spiders do not spin webs and are occasionally seen on tree trunks in gardens. They used to wait quietly on a vertical surface and rushed forward when bees reach within the closed range. Their exceptional agility and speed, as well as their ability to contort and squeeze through tight spaces, give them a strong advantage both in capturing prey and evading predators. They feed at night.

\section{Box spider (C. alyoni)}

C. alyoni is synanthropic, preferring to live near stingless bee hives. They usually build large irregular webs on sides or entrance of hives. Construct irregular webs in corners of ceilings and vibrates the web rapidly when it is touched.

\section{Economic potential of stingless bees}

The development of traditional meliponiculture enriched with scientific knowledge provides new opportunities for people in the urban and peri-urban and rural areas, especially women and it can improve the economics of many households and provide supplementary income. The non-aggressive and gentle behaviour when compared to other defensive stinging bees (Apis varieties) of stingless bees make women and children attractive in keeping stingless bees. Stingless beekeeping provides incomes to the rural poor through honey, cerumen (mixture of wax and plant resin) and resins production. Stingless honeybees produce beeswax and this form an important honeybee product. he beeswax is used as emulsifying agent for nearly all our modern cold creams, shoe polish production, wood polish, ointment, lipstick, pomade 
and rouges. Other industries using beeswax include food industries.

textile, ink, candle, crayon and pharmaceutical and

Table.1 Internal structure of the nest of Trigona iridipennis Smith

\begin{tabular}{|l|l|l|l|l|}
\hline \multirow{2}{*}{ Parameters } & \multicolumn{2}{|c|}{ Brood cells } & Pollen pots & Honey pots \\
\cline { 2 - 3 } & Worker/drone & queen & & \\
\hline Dimensions & & & & \\
a) Height & $3.72-3.98 \mathrm{~mm}$ & $7.12-7.43 \mathrm{~mm}$ & $0.7-1.2 \mathrm{~cm}$ & $0.6-1.1 \mathrm{~cm}$ \\
b) Diameter & $2.92-3.31 \mathrm{~mm}$ & $4.03-4.27 \mathrm{~mm}$ & $0.8-1.1 \mathrm{~cm}$ & $0.7-1.2 \mathrm{~cm}$ \\
\hline Shape & Oval & Oval & Oval & Oval \\
\hline Colour & Brown to cream & Brown to cream & Dark brown & Dark brown \\
\hline
\end{tabular}

Table.2 Trees harboring nests of Trigona iridipennis Smith in Kerala

\begin{tabular}{|l|l|l|l|}
\hline Sl.No & Common Name & Scientific name & Family \\
\hline 1 & Teak & Tectona grandis Linn. & Verbanaceae \\
\hline 2 & Maruthu* & Terminalia paniculata & Combretaceae \\
\hline 3 & Poovarasu* & Hopea glabra & Dipterocarpaceae \\
\hline 4 & Kanjiram* & Strychnox nuxvomica & Loganiaceae \\
\hline 5 & Neer mathalam* & Crateva religiosa & Capparidaceae \\
\hline 6 & Jack fruit tree & Artocarpus integrifolius & Moraceae \\
\hline 7 & Mango & Mangifera indica L & Caesalpiniaceae \\
\hline 8 & Tamarind & Tamarindus indica L & Caesalpiniaceae \\
\hline 9 & Manja vaka* & Albizia lebbeck & Fabaceae \\
\hline 10 & Manjium & Acacia manjium & Fabaceae \\
\hline 11 & Gul mohr & Poincinia regia $($ Delonix regia) & Caesalpiniaceae \\
\hline 12 & Neem & Melia azedirachta & Meliaceae \\
\hline 13 & Rain tree & Albizia saman & Fabaceae \\
\hline 14 & Silver oak & Grevillea robusta & Proteaceae \\
\hline 15 & Red wood & Adenanthera pavonia & Mimoceae \\
\hline 16 & Coconut & Cocos nucifera L & Palmae \\
\hline 17 & Arecanut & Areca catechu Linn. & Palmae \\
\hline 18 & Wild jack fruit tree & Artocarpus hirsutus Lam. & Moraceae \\
\hline
\end{tabular}

* Name in local language (Malayalam) 
Table.3 Plantation crops as source of nectar and pollen for Trigona iridipennis Smith in Kerala

\begin{tabular}{|l|l|l|l|l|}
\hline $\begin{array}{l}\text { Serial } \\
\text { number }\end{array}$ & Common name & Scientific name & Family & Source* \\
\hline 1 & Coconut & Cocos nucifera L. & Palmae & NP \\
\hline 2 & Arecanut & Areca catechu Linn. & Palmae & $\mathrm{P}$ \\
\hline 3 & Tea & Camellia sinensis & Camelliaceae & $\mathrm{P}$ \\
\hline 4 & Cashew & Anacardium occidentale & Anacardaceae & $\mathrm{NP}$ \\
\hline 5 & Coffee & Coffea arabica L. & Rubiaceae & $\mathrm{N}$ \\
\hline 6 & Rubber & Hevea brasiliensis & Euphorbiaceae & $\mathrm{N}$ \\
\hline 7 & Oil palm & Elacis guineensis & Aracaeceae & $\mathrm{P}$ \\
\hline 8 & Eucalyptus & Eucalyptus sp. & Myrtaceae & $\mathrm{NP}$ \\
\hline
\end{tabular}

* $\mathrm{N}=$ nectar, $\mathrm{P}=$ pollen, $\mathrm{NP}=$ nectar and pollen

Table.4 Medicinal plants as a source of nectar and pollen forTrigona iridipennis Smith in Kerala

\begin{tabular}{|c|c|c|c|c|}
\hline $\begin{array}{l}\text { Serial } \\
\text { number }\end{array}$ & Common name & Scientific name & Family & Source* \\
\hline 1 & Touch-me-not & Mimosa pudica & Mimosaceae & $\mathrm{P}$ \\
\hline 2 & Thulsi & Osmium sanctum & Laminaceae & $\mathrm{N}$ \\
\hline 3 & Puliyarila & Oxalis carniculata & Oxalidaceae & $\mathrm{N}$ \\
\hline 4 & Ixora & Ixora coccinea & Rubiaceae & NP \\
\hline 5 & Henna & Lowsonia alba & Lythraceae & $\mathrm{P}$ \\
\hline 6 & Castor & Ricinus communis & Euphorbiaceae & $\mathrm{N}$ \\
\hline 7 & Neem & Azadirachta indica & Meliaceae & $\mathrm{N}$ \\
\hline 8 & Nagadandi & Baliospermum monatanum & Euphorbiaceae & $\mathrm{N}$ \\
\hline 9 & Thazhuthama & Boerhavia diffusa & Nyctaginaceae & $\mathrm{N}$ \\
\hline 10 & Parijathum & Nyctanthes arbortristis & Oleaceae & $\mathrm{N}$ \\
\hline 11 & Phyllanthus & Phyllanthus niruri & Euphorbaceae & $\mathrm{N}$ \\
\hline 12 & Periwinkle & Vinca rosea & Apocynaceae & $\mathrm{N}$ \\
\hline 13 & Tridax & Tridax procumbens & Compositae & NP \\
\hline 14 & 'Kallurukky' & Scoparias dulce & Scrophulariaceae & $\mathrm{N}$ \\
\hline 15 & Sesbania & Sesbania rostrata & Papilionaceae & $\mathrm{N}$ \\
\hline 16 & 'Neela amari' & Indigofera tinctoria & Fabaceae & $\mathrm{P}$ \\
\hline 17 & Trumpet plant & Brugmansia suaveolens & Solanaceae & $\mathrm{P}$ \\
\hline 18 & $\begin{array}{l}\text { Javanese wool } \\
\text { plant }\end{array}$ & Aerva lanata & Amaranthaceae & $\mathrm{N}$ \\
\hline 19 & Kurumthotti & Sida cordiflorus & Malvaceae & NP \\
\hline 20 & Gladiolus & Gladiolus grandiflorus & Iridaceae & $\mathrm{NP}$ \\
\hline 21 & Thumba & Leucas aspera & Lamiaceae & NP \\
\hline
\end{tabular}

* $\mathrm{N}=$ nectar, $\mathrm{P}=$ pollen, $\mathrm{NP}=$ nectar and pollen 
Table.5 Ornamental plants as a source of nectar and pollen forTrigona iridipennis Smith in Kerala

\begin{tabular}{|c|c|c|c|c|}
\hline $\begin{array}{l}\text { Serial } \\
\text { number }\end{array}$ & Common name & Scientific name & Family & Source* \\
\hline 1 & Rose & Rosa sinensis L. & Rosaceae & $\mathrm{P}$ \\
\hline 2 & Anthurium & Anthurium andreanum & Arecaceae & $\mathrm{P}$ \\
\hline 3 & Marigold & Tagetes erecta & Compositae & $\mathrm{N}$ \\
\hline 4 & Gladiolus & Gladiolus grandiflorus & Iridaceae & $\mathrm{N}$ \\
\hline 5 & Euphorbia & Euphorbia milii & Euphorbiaceae & $\mathrm{P}$ \\
\hline 6 & Honey tree & Pittosporum sp & Pittosporaceae & $\mathrm{N}$ \\
\hline 7 & Garden palm & Cyrtostachys renda & Arecaceae & $\mathrm{N}$ \\
\hline 8 & Lilly & Pancratium sp & Amaryllidaceae & $\mathrm{P}$ \\
\hline 9 & Lotus & Nelumbo nucifera & Nelumbonaceae & $\mathrm{N}$ \\
\hline 10 & Manja vaka & Albizia lebbeck & Fabaceae & $\mathrm{P}$ \\
\hline 11 & Canna & Canna indica & Cannaceae & $\mathrm{N}$ \\
\hline 12 & Hamelia & Hamelia patens & Rubiaceae & $\mathrm{N}$ \\
\hline 13 & Balsum & Impatiens balsaminae & Balsaminaceae & $\mathrm{N}$ \\
\hline 14 & Ball lilly & $\begin{array}{l}\text { Haemanthus } \\
\text { cinnabarinus }\end{array}$ & Amaryllidaceae & $\mathrm{P}$ \\
\hline 15 & Bird of paradise & Helicona rostrata & Zingiberaceae & $\mathrm{N}$ \\
\hline 16 & Bottle brush & $\begin{array}{l}\text { Callistemon speciosus } \\
\text { DC. }\end{array}$ & Myrtaceae & NP \\
\hline 17 & Coral vine & Antigonum leptopus & Polygonaceae & NP \\
\hline 18 & Dragon plant & Dracaena fragrans & Agavaceae & NP \\
\hline 19 & Orchid & Spathoglottis plicata & Orchidaceae & $\mathrm{P}$ \\
\hline 20 & Gerbera & Gerbera sp. & Asteraceae & $\mathrm{N}$ \\
\hline 21 & Bauhinia & Bauhinta racemosa & Caesalpiniaceae & NP \\
\hline 22 & Ross-moss & Portulaca grandiflora & portulacaceae & $\mathrm{P}$ \\
\hline 23 & Cosmos & Cosmos bipinnatus & Asteraceae & $\mathrm{N}$ \\
\hline 24 & 'Venthi' & Tagetus erectus & Asteraceae & $\mathrm{N}$ \\
\hline 25 & Carnation & $\begin{array}{l}\text { Dianthus } \\
\text { caryophyllaceus }\end{array}$ & Caryophyllaceae & $\mathrm{N}$ \\
\hline 26 & Ixora & Ixora coccinea & Rubiaceae & $\mathrm{N}$ \\
\hline 27 & Sunflower & Helianthus annuum & Asteraceae & $\mathrm{N}$ \\
\hline 28 & Aerva & Aerva lanata & Amarantheceae & NP \\
\hline 29 & Nymphea & Nymphea stellata & Nympheaceae & $\mathrm{P}$ \\
\hline 30 & Peacock plant & Caesalpinia pulcherima & Caesalpiniaceae & NP \\
\hline 31 & Golden dewdrop & Canna indica & Cannaceae & $\mathrm{N}$ \\
\hline 32 & Poinsettia & Euphorbia pulcherima & Euphorbiaceae & $\mathrm{N}$ \\
\hline 33 & Cosmos & Cosmos sulfureus & Asteraceae & NP \\
\hline 34 & Yesterday-today & Brunfelria calycinae & Solanaceae & $\mathrm{N}$ \\
\hline 35 & Lonicera & Lonicera elaeagnoidea & Caprifoliaceae & $\mathrm{P}$ \\
\hline 36 & Celosia & Celosia cristata & Ameranthaceae & $\mathrm{N}$ \\
\hline 37 & Murraya & Murraya exotica & Rutaceae & $\mathrm{P}$ \\
\hline 38 & Blue & Petria volubilis & Verbenaceae & $\mathrm{N}$ \\
\hline
\end{tabular}


Int.J.Curr.Res.Aca.Rev.2021; 9(01): 1-30

\begin{tabular}{|l|l|l|l|l|}
\hline 39 & Euphorbia & Euphorbia heterophylla & Euphorbiaceae & N \\
\hline 40 & Trumpet plant & Brugmansia suaveolens & Solanaceae & N \\
\hline 41 & Portulaca & Portulaca oleraceae & Portulacaceae & NP \\
\hline 42 & Duranta & Duranta goldiana & Verbinaceae & N \\
\hline 43 & Gold spot & Duranta plumieri & Verbinaceae & N \\
\hline 44 & Golden rod & Solidago canadensis & Compositae & P \\
\hline 45 & Sage & Salvia splendens & Labiatae & P \\
\hline 46 & Jamanthi & Chrysanthemum sp. & Asteraceae & NP \\
\hline 47 & Coleostephus & Coleostephus sp. & Asteraceae & P \\
\hline 48 & Celosia & Celosia spicata & Amaranthaceae & P \\
\hline 49 & Hibiscus & Hibiscus rosa-sinensis & Malvaceae & P \\
\hline 50 & Tristellateia & Tristellateria australis & Malpighiaceae & NP \\
\hline 51 & Turnera & Turnera subulata & Turneraceae & NP \\
\hline 52 & Gardenia & Gardenta jasminoides & Rubiaceae & NP \\
\hline 53 & Murraya & Murraya paniculata & Rutaceae & NP \\
\hline 54 & Ehretia & Ehretia buxifolia & Myrsinaceae & P \\
\hline 55 & Pureria & Pureria sp. & Papilliionaceae & NP \\
\hline 56 & Aster & Celeosteplnus myconis & Asteraceae & NP \\
\hline 57 & Mimosa & Mimosa sp. & Mimosaceae & NP \\
\hline 58 & Rivina & Rivina humtlis & Phytolaccaceae & NP \\
\hline 59 & Urena & Urena lobata & Malvaceae & NP \\
\hline 60 & Ixora & Ixora parviflora & Rubiaceae & N \\
\hline 61 & Lily & Ltlium candidum & Liliaceae & NP \\
\hline
\end{tabular}

* $\mathrm{N}=$ nectar, $\mathrm{P}=$ pollen, $\mathrm{NP}=$ nectar and pollen

Table.6 Vegetable crops as a source of nectar and pollen forTrigona iridipennis Smith in Kerala

\begin{tabular}{|c|c|c|c|c|}
\hline $\begin{array}{l}\text { Serial } \\
\text { number }\end{array}$ & $\begin{array}{l}\text { Common } \\
\text { name }\end{array}$ & Scientific name & Family & Source* \\
\hline 1 & Brinjal & Solanum melongena L. & Solanaceae & $\mathrm{P}$ \\
\hline 2 & Bitter gourd & Momordica charantia L. & Cucurbitaceae & $\mathrm{P}$ \\
\hline 3 & Drumstick & Morinja oleifera & Moringaceae & NP \\
\hline 4 & Ash gourd & Benincasa hispida & Cucurbitaceae & $\mathrm{P}$ \\
\hline 5 & Snake gourd & Trichosanthes cucurmerina & Cucurbitaceae & $\mathrm{P}$ \\
\hline 6 & Curry leaf & Murraya koenigii & Rutaceae & $\mathrm{P}$ \\
\hline 7 & Chilly & Capsicum annum & Solanaceae & NP \\
\hline 8 & $\begin{array}{l}\text { Sponge } \\
\text { gourd }\end{array}$ & Luffa cylindrical & Cucurbitaceae & $\mathrm{P}$ \\
\hline 9 & Lady's finger & Abelmoschus esculentus & Malvaceae & $\mathrm{P}$ \\
\hline 10 & Bottle gourd & Lagenaria vulgaris & Cucurbitaceae & $\mathrm{P}$ \\
\hline 11 & Capsicum & Capsicum frutescens & Solanaceae & NP \\
\hline 12 & Sweet gourd & Momordica cochinchinensis & Cucurbitaceae & $\mathrm{P}$ \\
\hline 13 & Cheera & Amaranthus sp & Amaranthaceae & $\mathrm{P}$ \\
\hline 14 & Pumpkin & Cucurbito pepo & Cucurbitaceae & $\mathrm{P}$ \\
\hline
\end{tabular}

* $\mathrm{N}=$ nectar, $\mathrm{P}=$ pollen, $\mathrm{NP}=$ nectar and pollen 
Table.7 Fruit crops as a source of nectar and pollen for Trigona iridipennis Smith in Kerala

\begin{tabular}{|l|l|l|l|l|}
\hline Serial number & Common name & Scientific name & Family & Source* \\
\hline 1 & Mango & Mangifera indica L & Caesalpiniaceae & $\mathrm{NP}$ \\
\hline 2 & Papaya & Carica papaya L. & Caricaceae & $\mathrm{P}$ \\
\hline 3 & Guava & Psidium guajava L. & Myrtaceae & $\mathrm{P}$ \\
\hline 4 & Pomegranite & Punica granatum L. & Punicaceae & $\mathrm{P}$ \\
\hline 5 & Banana & Musa paradisica L & Musaceae & $\mathrm{P}$ \\
\hline 6 & Jack fruit tree & Artocarpus integrifolius & Moraceae & $\mathrm{P}$ \\
\hline 7 & Rambutan & Nephelium lappapeum & Sapindaceae & $\mathrm{N}$ \\
\hline 8 & Rose apple & Euginea jambosa & Myrtaceae & $\mathrm{NP}$ \\
\hline 9 & Loovi & Flacourtia inermis & Flacourtiaceae & $\mathrm{N}$ \\
\hline 10 & Carambola & Averrhoa carambola & Oxalidaceae & $\mathrm{P}$ \\
\hline 11 & Jamun & Eugenia cumini & Myrtaceae & $\mathrm{N}$ \\
\hline 12 & Passion fruit & Passiflora edulis Sims. & Passifloraceae & $\mathrm{NP}$ \\
\hline 13 & Gooseberry & Emblica officinalis & Euphorbiaceae & $\mathrm{P}$ \\
\hline 14 & Cherry & Carissa carandas & Apocynaceae & $\mathrm{N}$ \\
\hline 15 & Bilimbi & Averrhoa bilimbi & Oxalidaceae & $\mathrm{N}$ \\
\hline 16 & Litchi & Litchi chinensis & Sapindaceae & NP \\
\hline
\end{tabular}

* $\mathrm{N}=$ nectar, $\mathrm{P}=$ pollen, $\mathrm{NP}=$ nectar and pollen

Table.8 Condiments and spices as a source of nectar and pollen for Trigona iridipennis Smith in Kerala

\begin{tabular}{|l|l|l|l|l|}
\hline Serial number & Common name & Scientific name & Family & Source* \\
\hline 1 & Tamarind & Tamarindus indica L. & Caesalpiniaceae & N \\
\hline 2 & Cardamom & Elettaria cardamom & Zingiberaceae & NP \\
\hline 3 & Cinnamon & $\begin{array}{l}\text { Cinnamomum } \\
\text { zeylanicum }\end{array}$ & Lauraceae & $\mathrm{P}$ \\
\hline 4 & Mustard & Brassica juncea & Umbellifera & $\mathrm{N}$ \\
\hline 5 & Coriander & Coriandrum sativum L. & Umbelliferae & NP \\
\hline
\end{tabular}

* $\mathrm{N}=$ nectar, $\mathrm{P}=$ pollen, $\mathrm{NP}=$ nectar and pollen

Table.9 Field crops as a source of nectar and pollen for Trigona iridipennis Smith in Kerala

\begin{tabular}{|l|l|l|l|l|}
\hline Serial number & Common name & Scientific name & Family & Source* \\
\hline 1 & Tapioca & Manihot esculenta & & NP \\
\hline 2 & Gingelly & Sesamum indicum L. & Pedaliaceae & N \\
\hline 3 & Onion & Allium cepa & Liliaceae & NP \\
\hline 4 & Cotton & Gossypium hirsutm & Malvaceae & $\mathrm{P}$ \\
\hline 5 & Jute & Corchous olitorlus & Tiliaceae & $\mathrm{P}$ \\
\hline 6 & Pigeon pea & Cajanus cajan & Papilionaceae & $\mathrm{N}$ \\
\hline 7 & Sunflower & Helianthus annus L. & Asteraceae & $\mathrm{NP}$ \\
\hline 8 & Castor & Ricinus communis L. & Euphorbiaceae & $\mathrm{P}$ \\
\hline 9 & Jetropha & Jetropha sp. & Euphorbiaceae & $\mathrm{N}$ \\
\hline
\end{tabular}

* $\mathrm{N}=$ nectar, $\mathrm{P}=$ pollen, $\mathrm{NP}=$ nectar and pollen 
Table.10 Trees as a source of nectar and pollen for Trigona iridipennis Smith in Kerala

\begin{tabular}{|l|l|l|l|l|}
\hline $\begin{array}{l}\text { Serial } \\
\text { number }\end{array}$ & Common name & Scientific name & Family & Source* \\
\hline 1 & Fig & Ficus roxburghii & Moraceae & $\mathrm{P}$ \\
\hline 2 & Cannon Ball Tree & Cauropeta guineensis & Lecythidaceae & $\mathrm{NP}$ \\
\hline 3 & Cotton tree & Bombax malabarium & Malvaceae & $\mathrm{P}$ \\
\hline 4 & Birds cherry & Mundingia calbura & Verbinaceae & $\mathrm{NP}$ \\
\hline 5 & Sandal & Santalum album & Sandalaceae & $\mathrm{NP}$ \\
\hline 6 & Payyani & Paganelia longifolia & Bignoniaceae & $\mathrm{P}$ \\
\hline 7 & Soapnut & Sapindus emarginatus & & $\mathrm{NP}$ \\
\hline 8 & Teak & Tectona grandis Linn. & Verbanaceae & $\mathrm{P}$ \\
\hline 9 & Coper pod tree & Peltophorum roxburghii & Caesalpinaceae & $\mathrm{P}$ \\
\hline 10 & 'Ettilamaram' & Schefflera stellata & Araliaceae & $\mathrm{NP}$ \\
\hline 11 & Bilimbi & Averrhoa bilimbi & Oxalidaceae & $\mathrm{N}$ \\
\hline 12 & Jack tree & Artocarpus integrifolius & Moraceae & $\mathrm{P}$ \\
\hline 13 & Oil palm & Elacis guineensis & Aracaceae & $\mathrm{P}$ \\
\hline 14 & 'Nagappoomaram' & Couropita guianensis & Lecithidaceae & $\mathrm{NP}$ \\
\hline 15 & Bombax & Bombax malabarium & Malvaceae & $\mathrm{P}$ \\
\hline
\end{tabular}

* $\mathrm{N}=$ nectar, $\mathrm{P}=$ pollen, $\mathrm{NP}=$ nectar and pollen

Table.11 Shade trees as a source of nectar and pollen for Trigona iridipennis Smith in Kerala

\begin{tabular}{|l|l|l|l|l|}
\hline $\begin{array}{l}\text { Serial } \\
\text { number }\end{array}$ & Common name & Scientific name & Family & Source* \\
\hline 1 & Wild Tapioca & Manihot glaziovi & Euphorbiaceae & NP \\
\hline 2 & Glyricidia & Glyricidia maculate & papilionaceae & $\mathrm{N}$ \\
\hline 3 & Birds cherry & Mundingia calbura & Verbinaceae & $\mathrm{NP}$ \\
\hline 4 & Agave & Agave americana & Agavaceae & $\mathrm{NP}$ \\
\hline 5 & Coper pod tree & Peltophorum roxburghii & Caesalpinaceae & $\mathrm{P}$ \\
\hline 6 & Elengi & Mimus elengi & Sapotaceae & $\mathrm{NP}$ \\
\hline
\end{tabular}

* $\mathrm{N}=$ nectar, $\mathrm{P}=$ pollen, $\mathrm{NP}=$ nectar and pollen 
Fig.1 Description of the stingless bees across Bangalore a) natural habitat on mud walls; b) habitat on stone walls; f) colony showing brood and stored honey and pollen
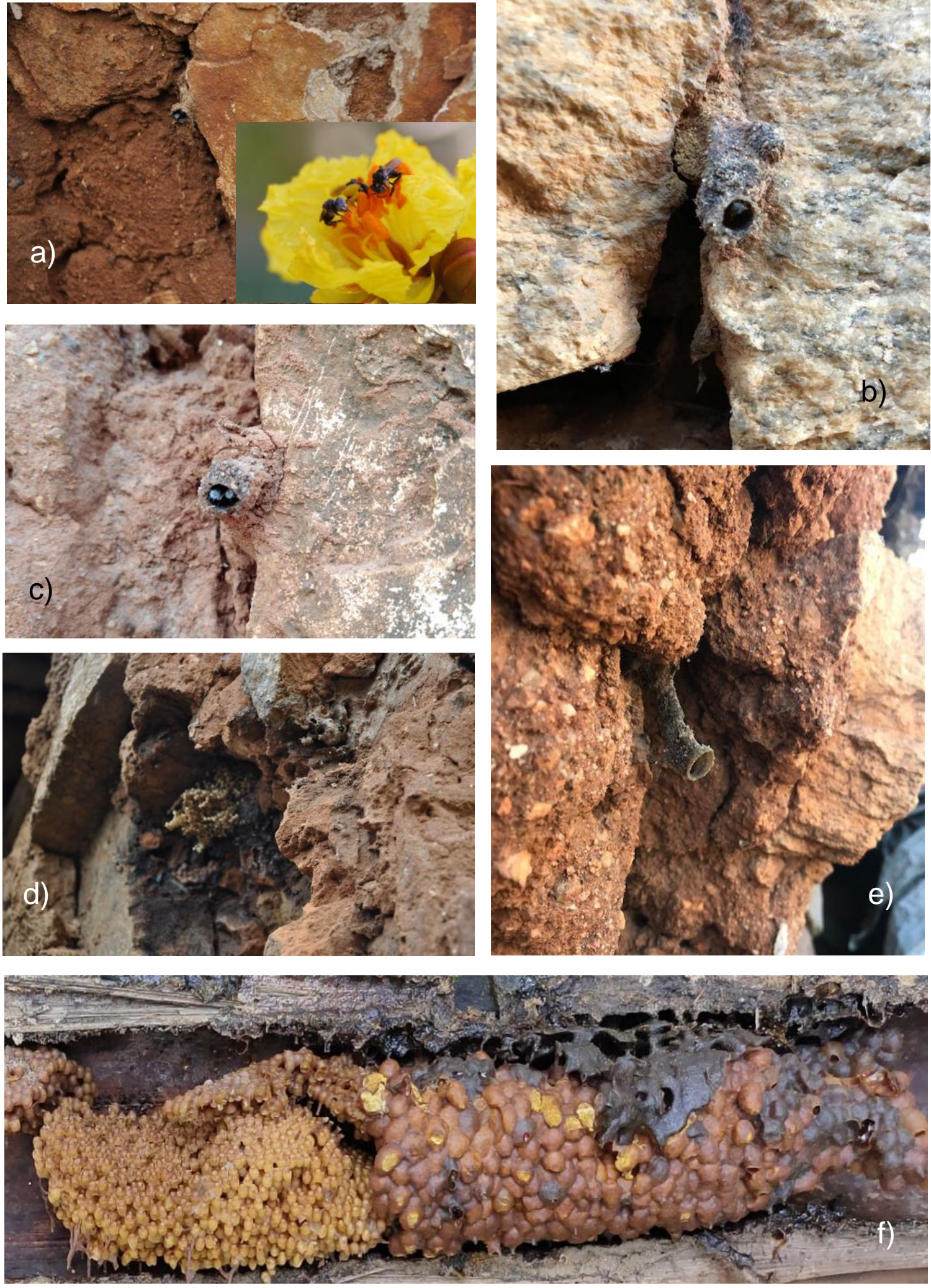
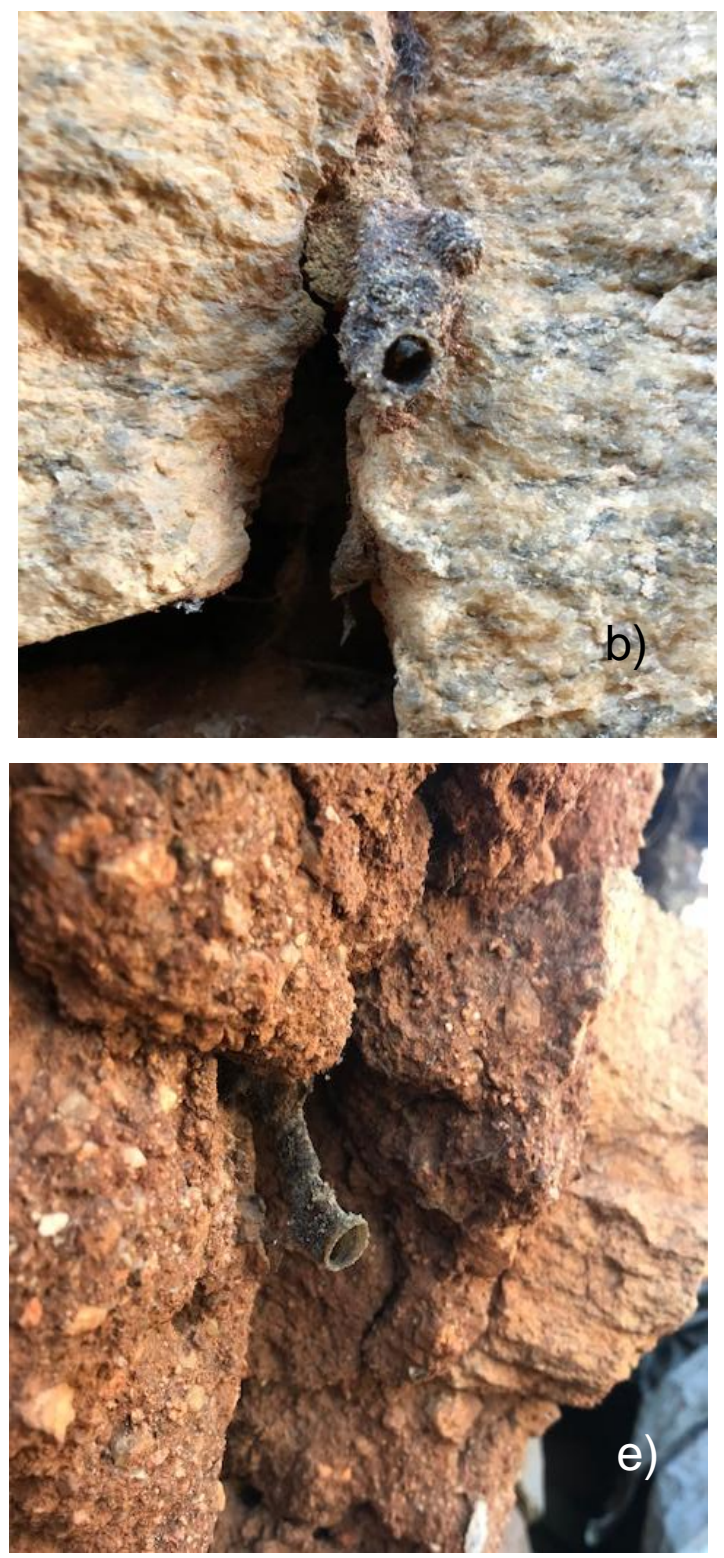
Fig.2 Schematic representation of stingless bees in differ habitats a) bamboo pole; b) wooden box; c) inside a tree cavity

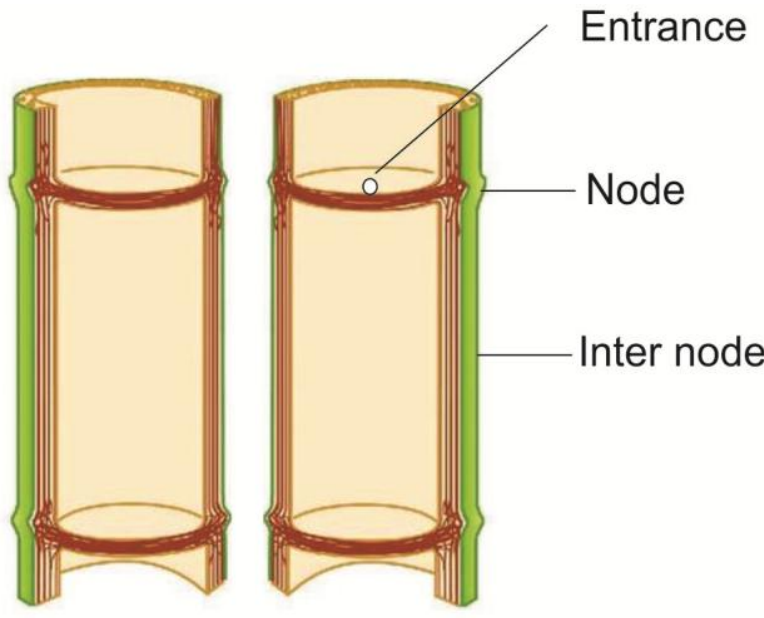

a)

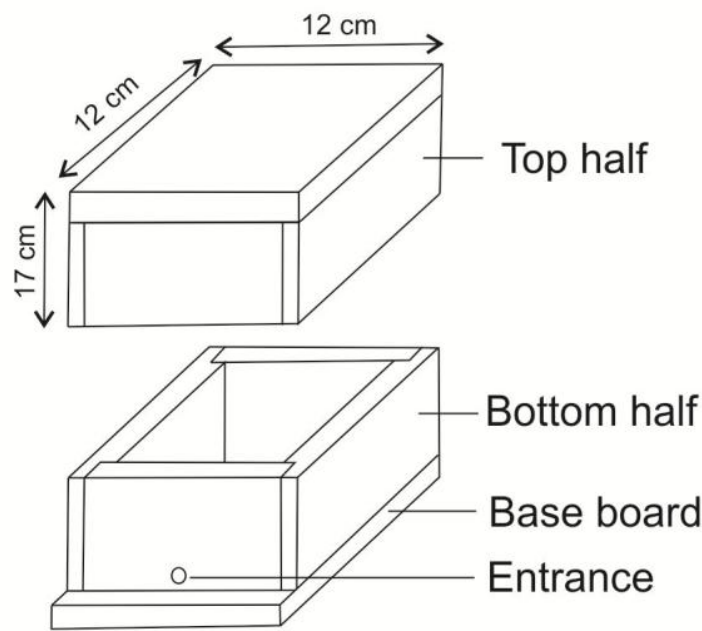

b)

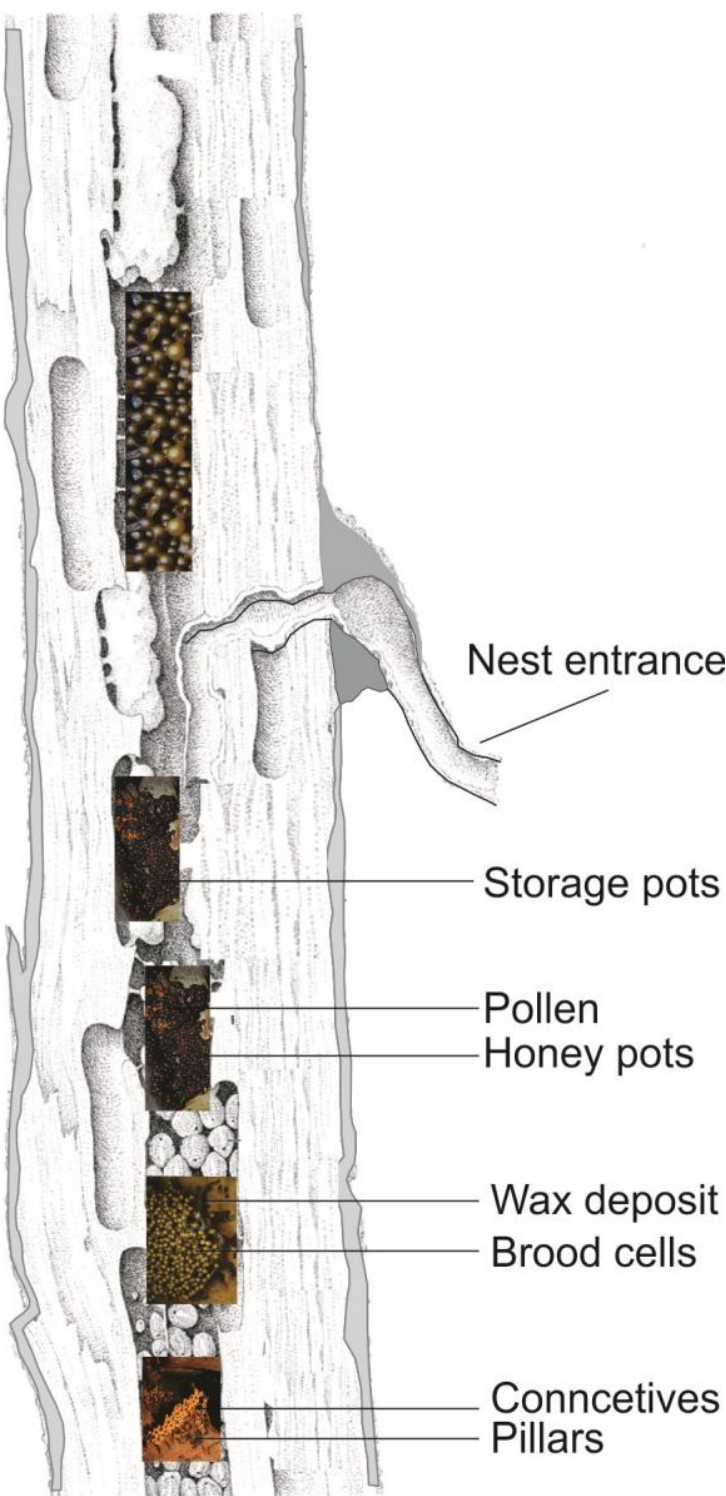

c) 
Fig.3 Different types of bee nests a) hives placed on the stand; b) PVC pipe nest; c) earthen pot nest; d) nest in coconut shell; e) bamboo pole nest; f) earthen bowl nest exposed; g) log nest; h) nest in garden pot; i) two tier earthen bowl nest
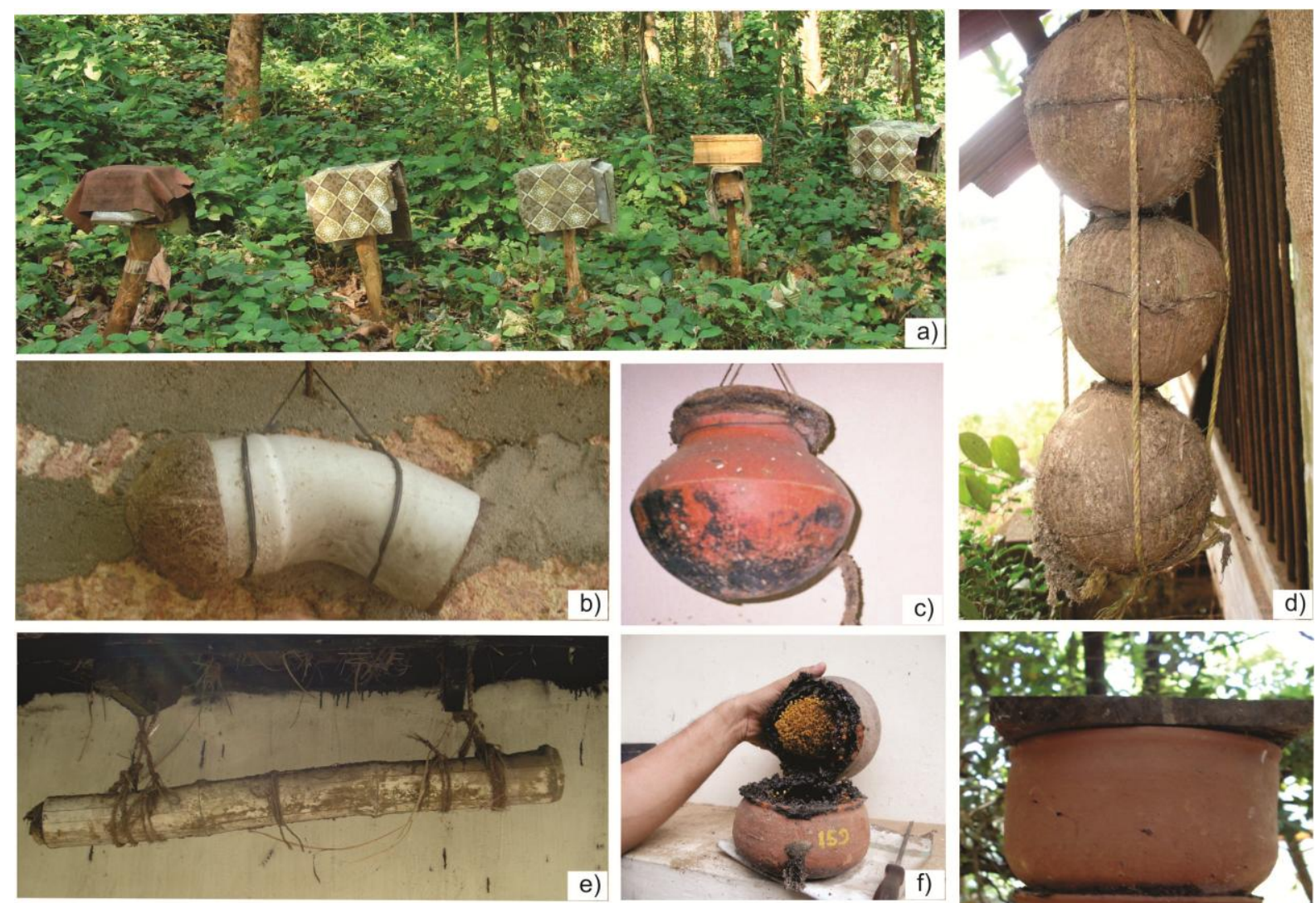

c)
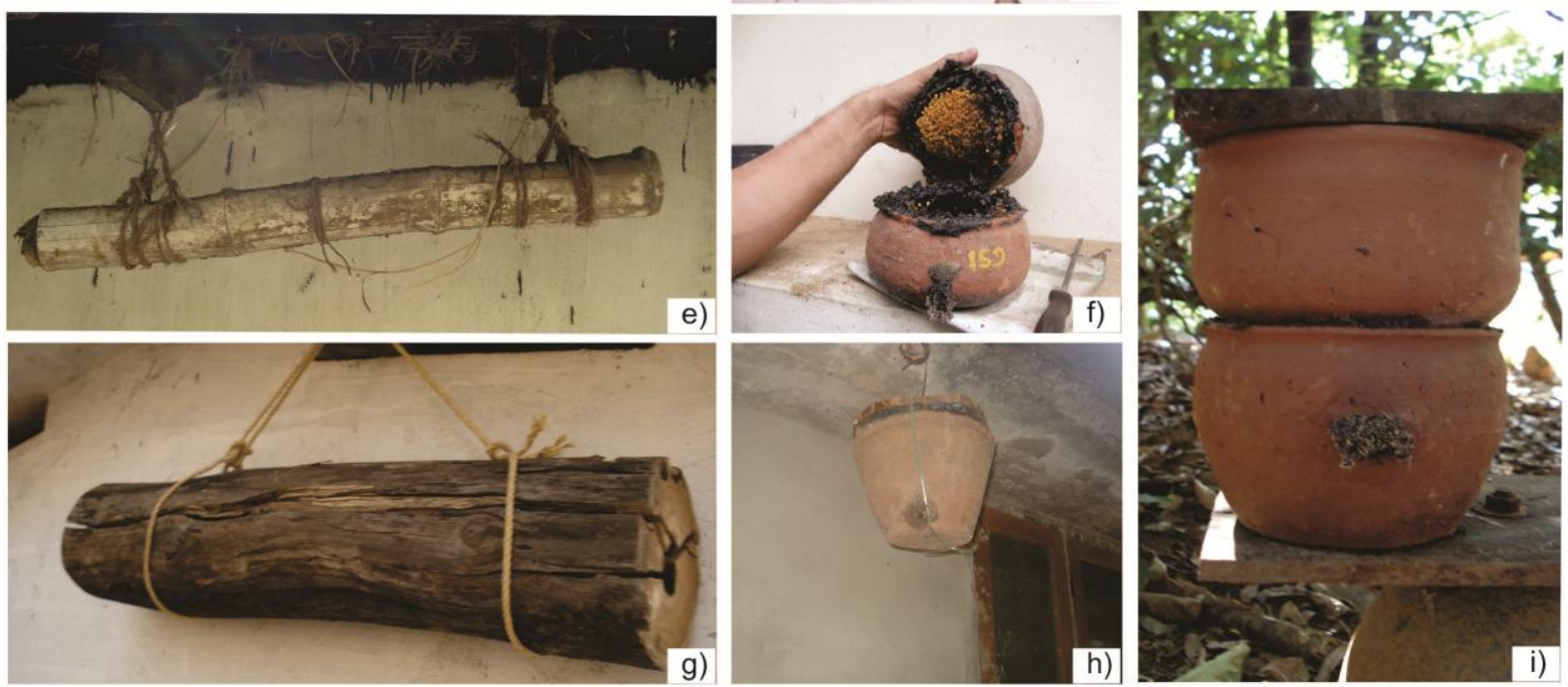
Fig.4 Different life stages of $H$. illucens a) adult of H. illucens b) maggot of $H$. illucens c) maggots of $H$. illucens from a damaged hive d) pupae of $H$. illucens from a damaged hive e) dorsal view of Aethina sp. f) ventral view of adult Aethins sp. Photo Courtesy: Jayalekshmi C. R.
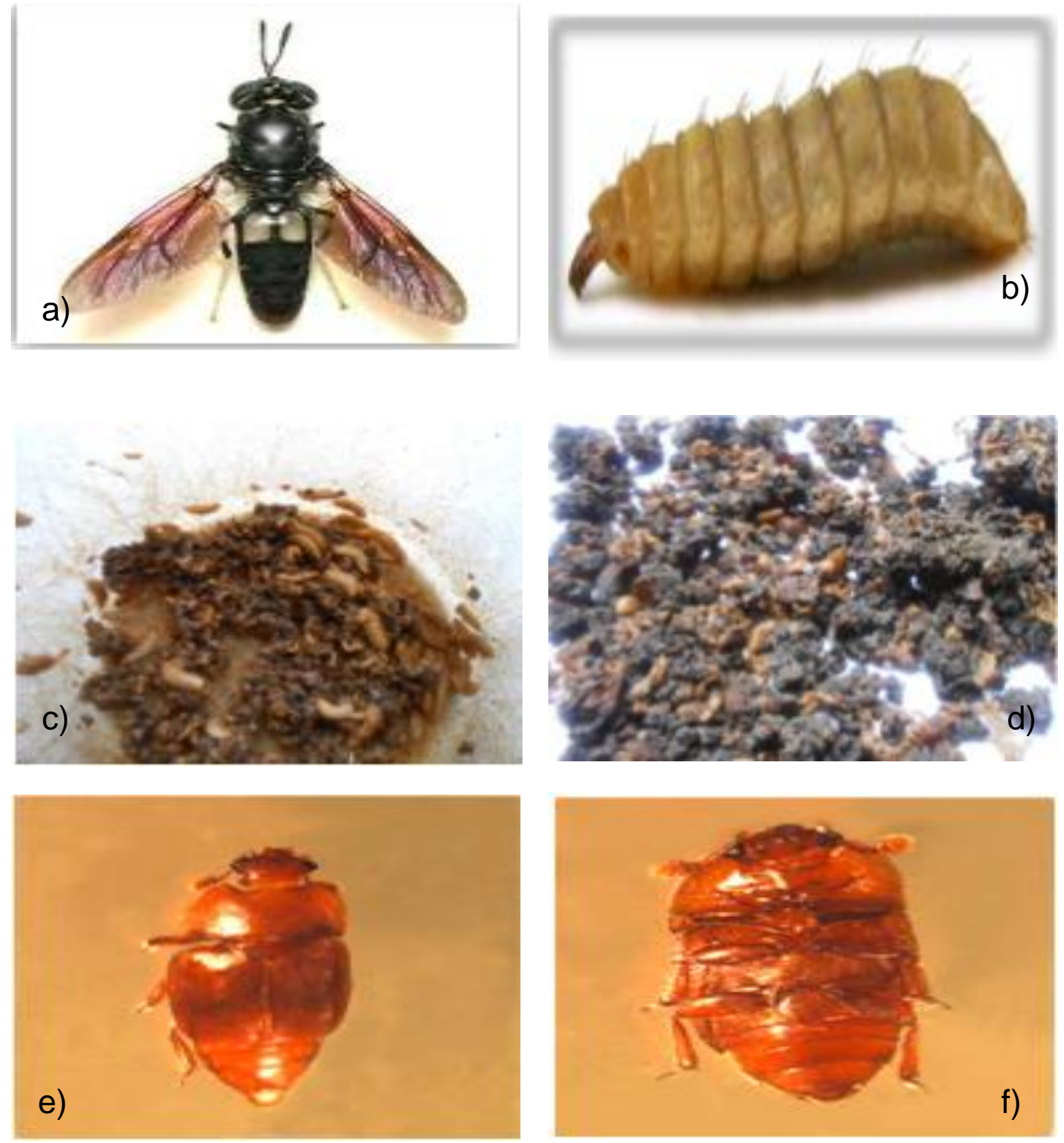
Fig.5 Different life stages of Aethina sp. a) eggs of Aethina sp. b) grub of Aethina sp. c) close up view of pupae of Aethina sp. d) adult of $A$. siva e) nymph of A. siva f) adult of Sycanus sp. Photo Courtesy: Jayalekshmi C. R.

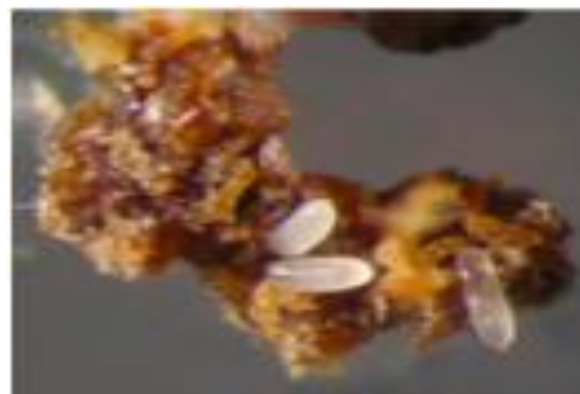

a)

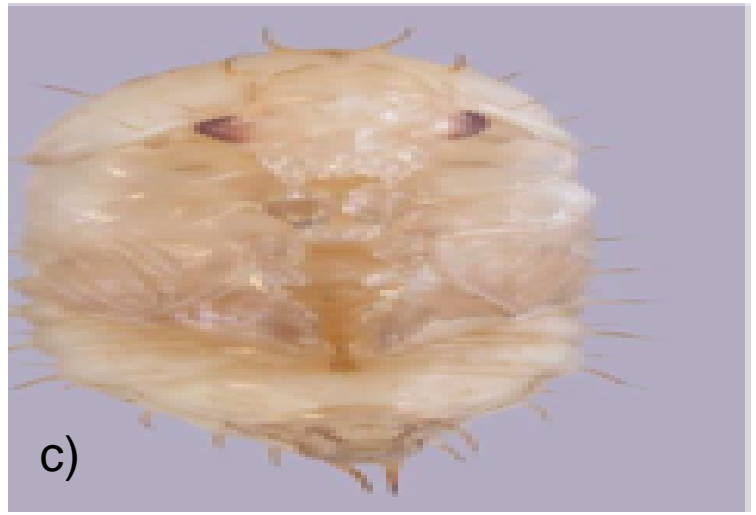

e)

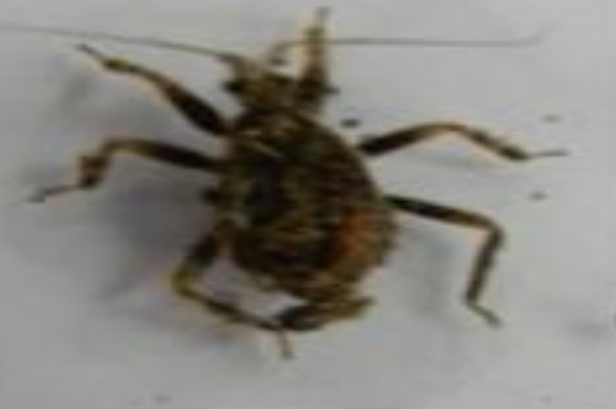

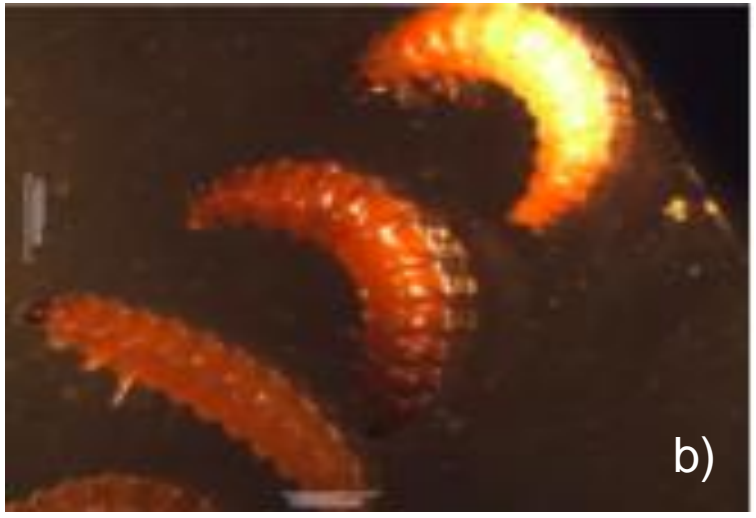

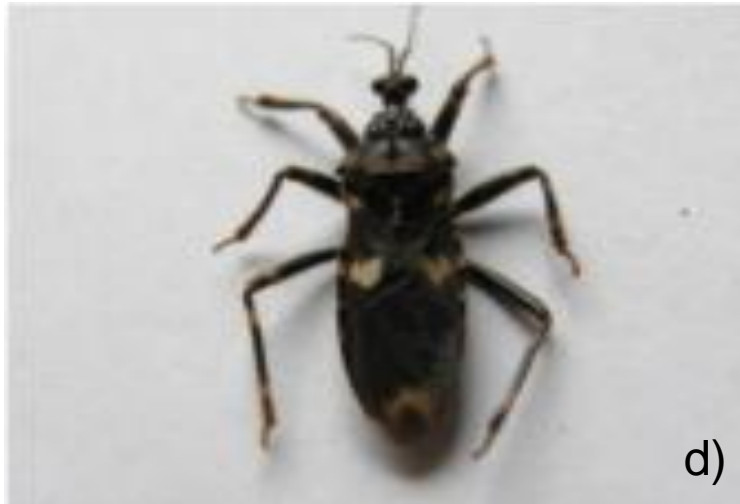

d)

f)

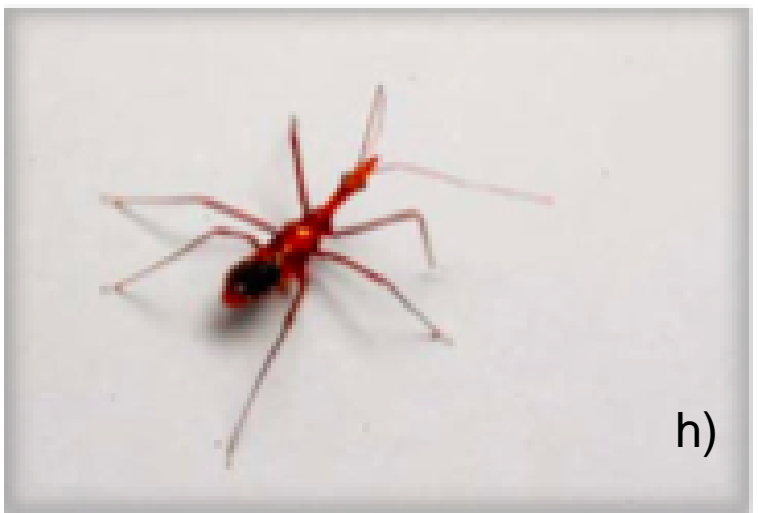


Fig.6 Description of a) adult T. projectusb) Thomisus loboscus c) adult Neoscona nautical d) Menemerus bivittatus e) Hersilia savignyi f) Plexippus paykulli g) Heteropoda venatoria

h) Crossopriza lyoni. Photo Courtesy: Jayalekshmi C. R.
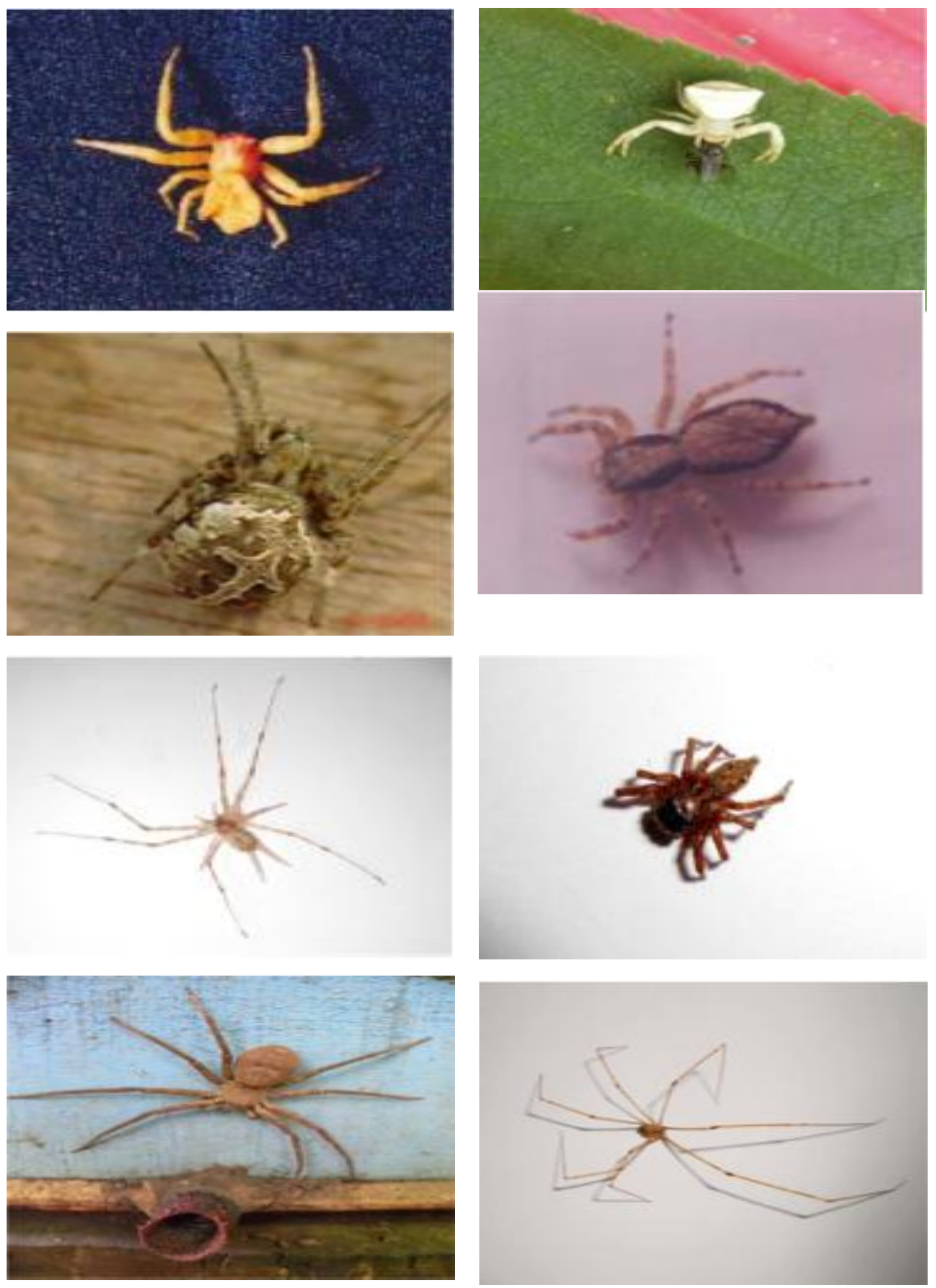
Fig.7 Description of a) $P$. variotii infection in hive b) $P$. variotii culture in PDA c) microscopic characters of $P$. variotii $(400 \mathrm{X}) \mathrm{d})$ cultural characters of A. niger in PDA e) conidophores of A. niger $(100 \mathrm{X}) \mathrm{f})$ microscopic characters $(400$ $\mathrm{X})$. Photo Courtesy:Jayalekshmi C. R.
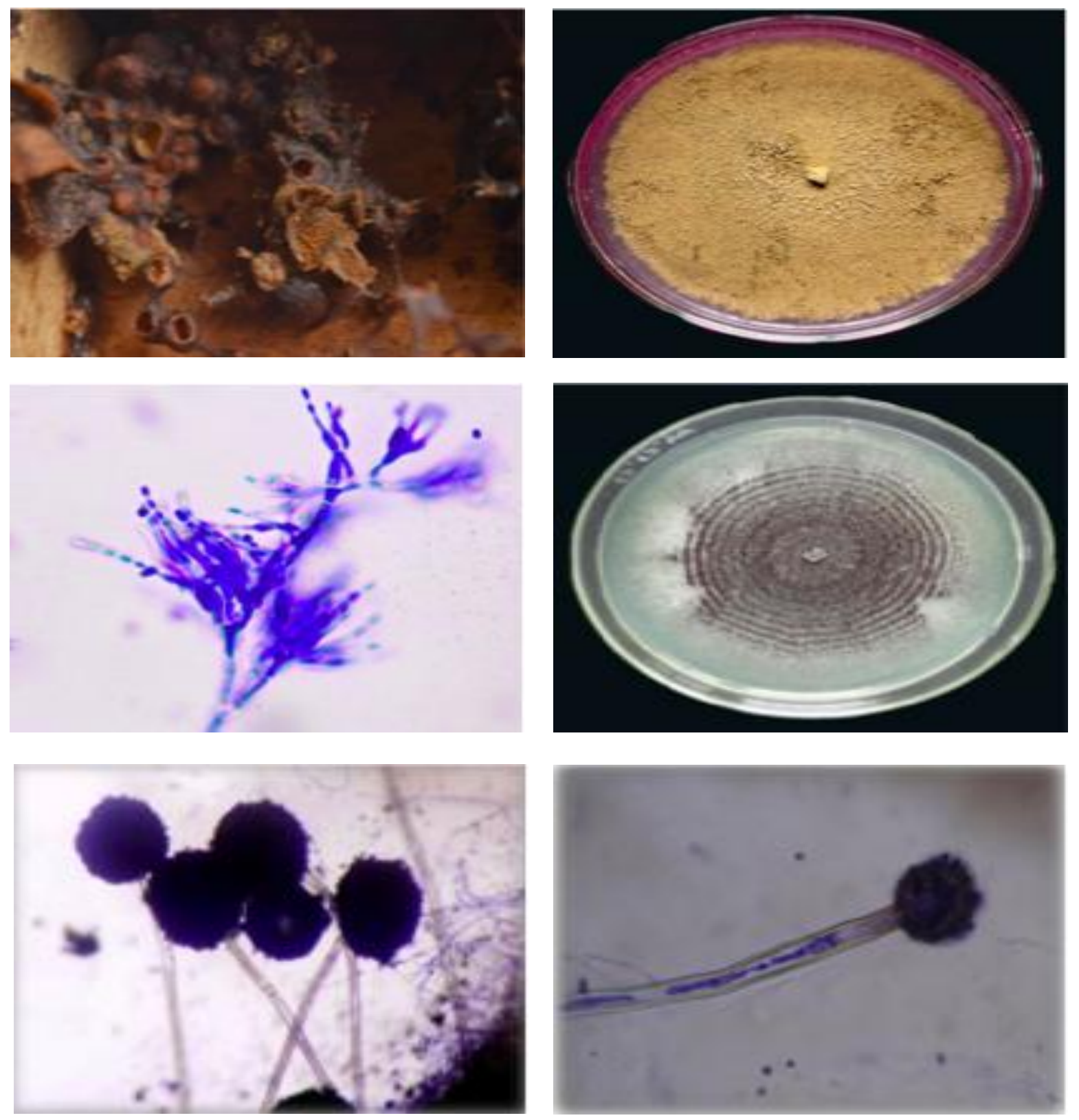
Fig.8 Description of a) Maggots of H. illucens inside severely infested hive b) and c) grubs of Aethina sp. on brood cells and honey pots d) Black soldier fly (Hermetia illucens) e) Black soldier fly (Hermetia illucens) grubs. Photo Courtesy:Jayalekshmi C. R. and Wikipedia
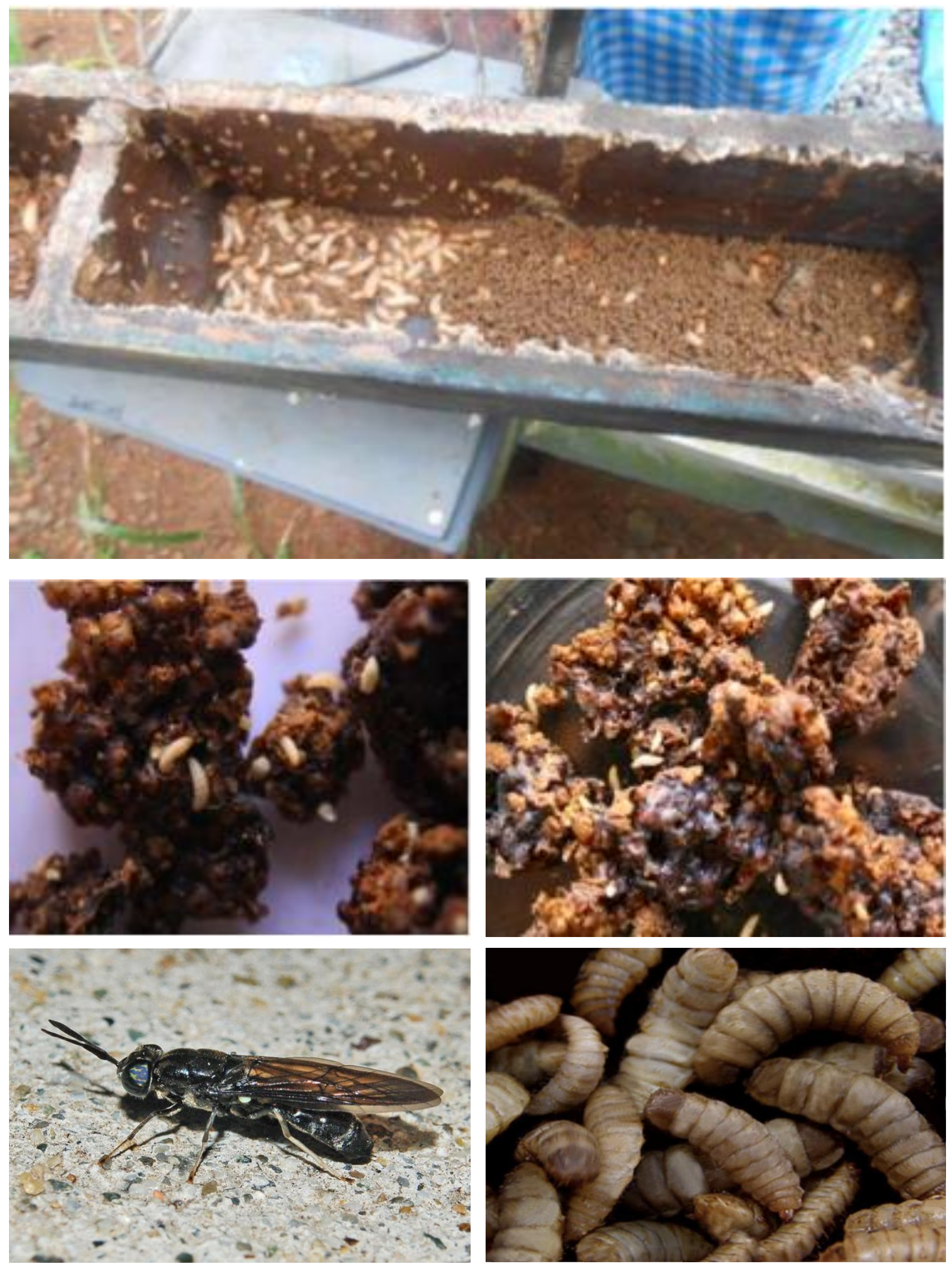
Despite the high market for stingless bee honey, beeswax and pollen in both local and international markets, their production and processing are not common in Karnataka and so these honeybees products are not much and readily available in the market. The stingless bees honey is sold in market places at a higher price than honey from Apis bees (Sanford, 1997). More information could therefore be made available on the production, processing and utilization of stingless honeybee honey, beeswax and pollen. Also high quality honey, beeswax and pollen could be provided for food and pharmaceutical industries and generate employment for the youths.

Another attractive feature of meliponiculture is that the meliponine bees are 'stingless'. Unlike the situation in keeping the honeybee, beekeepers need not purchase expensive, protective clothing in order to manage and handle hives or to harvest and collect products (honey, propolis, beebread) with melipona. Thus meliponiculture can be viewed as both a compliment and advancement of the honey bee industry (Apiculture).

The antimicrobial and anticancer activity of stingless bee honeys may lead to the use of these honeys in medicinal products. Moreover in the current Covid-19 pandemic situations, the stingless bee honey may act as an immunity booster and enhance the immune system. Certainly, stingless bee honey, with its delicate taste, does fit very well in the present development of export market for speciality honey.

In addition, the role of stingless bees as providers of ecosystem services vital to the survival of several forest plants and crop species through pollination has also become a source of income generation activity. In Australia, stingless beekeepers offer stingless bee services for crop pollination, usually as their secondary financial activity (Cortopassi-Laurino et al., 2006).

In conclusion, Trigona iridipennis Smith shows great diversity in plant selection for dietary as well as resin sources. The shift towards ornamental plants for foraging may be an adaptation evolved in response to human modification of the environment. The bees collect resin from a variety of sources for building nest, its maintenance and also for defence. Bee traffic is found to be related to time, season, and strength of the colony. The study also highlights the various food sources of
Trigona iridipennis Smith in Kerala which can be further explored for flourishing meliponiculture.

The potential benefit from meliponiculture can be tapped if a concerted effort is moved toward developing a sustainable approach to beekeeping in Africa and Nigeria in particular. Several ways in which this could be accomplished is through attainment of a proper understanding of the meliponine life cycle, discovery of new ways to increase honey yield and through better bee management, including sanitary practices, the housing of colonies, multiplication and harvest procedures. In all places where meliponiculture develops, bottlenecks for their improvement include how to keep and conserve their honey, how to rear them in large quantities, how to prevent colonies from being contaminated by agricultural pesticides and maintain the bees, how to use their services and conserve their populations, and how to provide qualified information and training in all levels. A non-destructive approach in breeding, propagating and relocating of bees using pheromone technology will ensure environmental sustainability.

The adult black soldier fly, $H$. illucens fly which thrived on decaying organic matter occasionally found entry into the stingless bee hives through the entrance tube, especially on weak colonies. The adult fly did not feed on the brood, pollen and honey pots but the larval stage of the pest damaged the colonies. The nitidulid beetle Aethina sp. damaged brood cells, pollen and honey pots.

Both the grubs and adults of beetle were observed in the rear portion of the brood, pollen, honey pots of decaying hive materials. They completed their life cycle inside the damaged hives. The nymphs of the predator, reduviid bug A. siva camouflaged themselves by attaching bits of bee cadaver on to their body and remained close to the entrance tube of the colonies. The adults and nymphs of predator assassin bug Sycanus sp. were observed around the hives, crevices and on tree trunks in the vicinity of stingless bee hives. Eight different types of predatory spiders were observed from the hive entrance and foraging plants of stingless bee colonies.

Two fungal isolates of Paecilomyces variotii were obtained from Thiruvananthapuram district while a single isolate of Aspergillus niger was recorded from Pathanamthitta district. P. variotii was isolated from pollen pots, honey pots, propolis and on the walls of the affected hives. No dead bees were found in the hives from which $P$. variotii was isolated. The fungus was cultured on PDA and produced pale cream coloured 
colonies which appeared floccose and powdery due to dense production of conidiophores. The microscopic characters of $P$. varotii revealed dense and vertically arranged whorls or branches of conidiophores. Each conidiophore bears single to many hyaline to light yellow phialides, $30-100 \mu \mathrm{m}$ in length. The fungus $A$. niger was isolated from dead bees lying inside the hive floor but it did not infect or contaminate the hive or its components. The fungus produced white mycelium on PDA, covered $9.0 \mathrm{~cm}$ in 12 days, conidiophores were hyaline and 500- $1000 \mu \mathrm{m}$ in length. Thus the microscopic characters showed that the fungus possessed large globose conidial head (vesicle) and was dark brown in colour. Conidia were globose to subglobose 3-4 $\mu \mathrm{m}$ with rough surface.

Even though bamboo hives were less prone to the attack of pests and diseases, majority of the beekeepers used wooden hives for domesticating stingless bees since it is easier to handle during colony division, honey harvesting and periodical observations on need basis. Considering the height from the ground level, no incidence of pests, predators and diseases were recorded in the colonies maintained at 3-5 feet. Thus, for scientific meliponiculture, the colonies can be domesticated in wooden hives, it is to be placed at 3-5 feet above ground level which facilitate easy handling with least incidence of pests, predators and diseases which in turn will help in the appreciable yield of honey and augment pollination of flora.Finally, a sustainable utilization of stingless bees is considered to be an enhancer of pollination services both in an agricultural crop and natural ecosystem.

\section{Acknowledgment}

This review article will not be possible by the encouragement and support from Dr. K. B. Umesh, Dr. Andreas Buerkert, Dr. Prasanna Kumar P. S, Dr. Veerabhadrappa Bellundagi, Dr. Hamsa K.R and Dr. Catrin Westphal.

\section{References}

AICRP [All India Coordinated Research Project on Honey bees and Pollinators]. 2004. Final report of ICAR Adhoc Scheme on Bioecology, domestication and management of stingless bees. Indian Council of Agricultural Research. New Delhi, 76p.

Anderson, D. and Gibbs, A. 1982. Viruses and Australian Native bees. J. Kans. Entomol. Soc. 55: 131-134.
Baker, E. W., and Delfinado-Baker, M. (1985). An unusual new species of Neocypholaelaps (Acari: Ameroseiidae) from the nests of stingless bees (Apidae: Meliponinae). International Journal of Acarology, 11(4), 227-232.

Baker, E.W. and Delfinado, M. 1985. An unusual species of Neocypholaelaps (Acari: Amerosiidae) from Asia. Int. J. Acarol. 14: 127-136.

Baker, R. A., and Chmielewski, W. 2003. How old are bees? A look at the fossil record. Journal of Apicultural Science, 47(1): 79-86.

Biesmeijer, K. 1993. Stingless bees: discussion and paper at the International symposium on pollination tropics Pegone, 1: 6-8.

Biluca, F. C., Braghini, F., Gonzaga, L. V., Costa, A. C. O., and Fett, R. 2016. Physicochemical profiles, minerals and bioactive compounds of stingless bee honey (Meliponinae). Journal of Food Composition and Analysis, 50(1): 61-69.

Byarugaba, D. (2004). Stingless bees (Hymenoptera: Apidae) of Bwindi impenetrable forest, Uganda and Abayanda indigenous knowledge. International Journal of Tropical Insect Science, 24(1), 117-121.

Camargo, J. M. F., and Pedro, S. R. M. 1992. Sytematics, phylogeny and biogeography of the Meliponinae (Hymenoptera, Apidae): A mini-review. Apidologie, 23(1): 509-522.

Camargo, J. M. F., and Posey, D. A. 1990. Knowledge of the Kayapo on stingless social bees (Meliponidae, Apidae, Hymenoptera): additional notes. Boletim do Museu Paraense Emílio Goeldi. Nova Série, Zoologia, 6(1): 17-42.

Cortopassi-Laurino, M., Imperatriz-Fonseca, V. L., Roubik, D. W., Dollin, A., Heard, T., Aguilar, I., and Nogueira-Neto, P. 2006. Global meliponiculture: challenges and opportunities. Apidologie, 37(2): 275-292.

Costa, M. A., Del Lama, M. A., Melo, G. A., and Sheppard, W. S. 2003. Molecular phylogeny of the stingless bees (Apidae, Apinae, Meliponini) inferred from mitochondrial 16S rDNA sequences. Apidologie, 34(1): 73-84.

Craig, C. L., Weber, R. S., and Bernard, G. D. (1996). Evolution of predator-prey systems: spider foraging plasticity in response to the visual ecology of prey. The American Naturalist, 147(2), 205-229.

Crane, E. 1992. The past and present status of beekeeping with stingless bees. Bee World, 73(1): 29-42.

Devanesan, S., Premila, K. S., and Shailaja, K. K. 2017. Meliponiculture for Pollination Support, Yield Enhancement and Poverty Eradication. In 
Biodiversity for Sustainable Development (pp. 267272). Springer, New York, USA.

Divya, K., Amritha, V., and Devanesan, S. (2016). Nest architecture of stingless bees. Advances in Life Sciences, 5(6), 2035-2038.

Eltz, T., Brühl, C. A., Van der Kaars, S., and Linsenmair, E. K. 2002. Determinants of stingless bee nest density in lowland dipterocarp forests of Sabah, Malaysia. Oecologia, 131(1): 27-34.

Fain, A., and Flechtmann, C. H. W. (1985). Acari domum meliponinarum brasiliensium habitantes. XI. Meliponopus palpifer gn, sp. $\mathrm{n}$. from the bee Melipona seminigra (Meliponidae). International Journal of Acarology, 11(2), 89-91.

Flechtmann C. H. W., and Camargo, C. A. (1974). Acari associated with stingless bees (Meliponidae, Hymenoptera) from Brazil. Proceedings of the International Congress of Acarology, Saafelden, 315-319.

Garedew, A., Schmolz, E., and Lamprecht, I. 2004. Microcalorimetric investigation on the antimicrobial activity of honey of the stingless bee Trigona spp. and comparison of some parameters with those obtained with standard methods. Thermochimica Acta, 415(1-2): 99-106.

George, C. J. 1934. The bionomics, morphology and metamorphosis of Melipona iridipennis. J. Univ. Bombay, 5: 1-16.

Gupta, R. K. 2014. Taxonomy and distribution of different honeybee species. In Beekeeping for poverty alleviation and livelihood security (pp. 63103). Springer, Berlin, Germany.

Hamida, B. T. 1999. Enemies of bees. In: Colin M.E., Ball B.V., Kilani M. (eds), Bee disease diagnosis (25th Ed.). CIHEAM, Tunisia, pp. 147- 165.

Heard, T. A. 1999. The role of stingless bees in crop pollination. Annual Review of Entomology, 44(1): 183-206.

Kajobe, R., and Roubik, D. W. 2006. Honey- making bee colony abundance and predation by apes and humans in a Uganda forest reserve 1. Biotropica: The Journal of Biology and Conservation, 38(2): 210-218.

Kiatoko, N. 2012. Distribution, behavioural biology, rearing and pollination efficiency of five stingless bee species (Apidae: Meliponinae) in Kakamega forest, Kenya. Ph.d Thesis. Pure and Applied Science of Kenyatte University, Kenya.140-226 pp.

Leonard, F.W. (1983). Investigation on the fauna associated with the pollen collected by honeybees, Apis mellifera. MSc thesis, University of Maryland, College Park, 43p.
Michener, C. D. 1990) Classification of the Apidae (hymenoptera). The University of Kansas Science Bulletin, 54(4): 75.

Michener, C. D., and Boongird, S. (2004). A new species of Trigona from peninsular Thailand (Hymenoptera: Apidae: Meliponini). Journal of the Kansas Entomological Society, 77(2), 143-146.

Michener, C.D. 1974. The social behaviour of the bees. A comparative study. Belknap, Harvard University Press, Cambridge, Mass.404pp.

Nair, M.C. 2003. Apiculture resource biodiversity and management in southern Kerala. Ph.D. thesis. Mahatma Gandhi University, Kottayam, 277.

Nisha, M. M. 2002. Management of stingless bee Trigona iridipennis Smith (Meliponinae: Apidae) in the homesteads of Kerala. M.Sc (Ag.) thesis, Kerala Agricultural University, Thrissur. pp. 62-63.

Posey, D. A., and de Camargo, J. M. F. 1985. Additional notes on the classification and knowledge of stingless bees (Meliponinae, Apidae, Hymenoptera) by the Kayapó Indians of Gorotire, Pará, Brazil. Carnegie Museum of Natural History.

Premila, K. S., Devanesan, S., and Shailaja, K. K. 2013. Reduviid bug Acanthaspis siva - A predator of honey bee and stingless bee in Kerala. Insect Environ. 19: 3p.

Quezada-Euán JJG. 2018) Stingless bee of Mexico: The Biology, Management and Conservation of an Ancient Heritage. Cham: Springer; 2018. 294p.

Raakhee, M. 2000. Bioecology and management of stingless bees (Apidae: Meliponinae). M. Sc.(Ag.) thesis, Kerala Agricultural University, Thrissur, 68.

Rao, D., Cheng. K., and Herberstein, M. E. 2008. Stingless bee response to spider webs is dependent on the context of encounter. Behav. Ecol. Sociobiol. 63: 209- 216.

Rasmussen, C. (2013). Stingless bees (Hymenoptera: Apidae: Meliponini) of the Indian subcontinent: Diversity, taxonomy and current status of knowledge. Zootaxa, 3647(3), 401-428.

Rasmussen, C., and Cameron, S. A. 2007. A molecular phylogeny of the Old World stingless bees (Hymenoptera: Apidae: Meliponini) and the non- monophyly of the large genus Trigona. Systematic Entomology, 32(1): 26-39.

Rasmussen, C., and Cameron, S. A. 2010. Global stingless bee phylogeny supports ancient divergence, vicariance, and long distance dispersal. Biological Journal of the Linnean Society, 99(1): 206-232. 
Roubik, D. W. 1989. Ecology and natural history of tropical bees. Cambridge university Press, New York, USA.

Roubik, D. W. 2000. Pollination system stability in tropical America. Conservation Biology, 12351236.

Roubik, D. W. 2006. Stingless bee nesting biology. Apidologie, 37(2): 124-143.

Sakagami, S. F. (1978). Tetragonula stingless bees of the continental Asia and Sri Lanka (Hymenoptera, Apidae). Journal. Series 6. Zoology.

Sakagami, S. F. 1982. Stingless bees. Social Insects, 3: 361-423.

Silva, A.C. and Gl-Santana, H. R. 2004. Predation of Apiomerus pillipes (Fab.) (Hemiptera, Reduviidae, Harpactorinae, Apiomerini) over meliponinae bees (Hymenoptera, Apidae) in the state of Amazonas, Onas, Brazil. Revista Brasileria de Zoologia. 21: 769 - 774.

Slaa, E. J., Chaves, L. A. S., Malagodi-Braga, K. S., and Hofstede, F. E. 2006. Stingless bees in applied pollination: practice and perspectives. Apidologie, 37(2): 293-315.

Sommeijer, M. J. (1999). Beekeeping with stingless bees: a new type of hive. Bee world, 80(2), 70-79.

Swaminathan, T. 2000. Studies on stingless bees. M. Sc. (Ag) Thesis, Tamil Nadu Agricultural University, Coimbatore, 120.

Thompson, H. M., and Hunt, L. V. (1999). Extrapolating from honeybees to bumblebees in pesticide risk assessment. Ecotoxicology, 8(3), 147-166.

Thompson, H. M., and Thorbahn, D. (2009). Review of honeybee pesticide poisoning incidents in Europeevaluation of the hazard quotient approach for risk assessment. Julius-Kühn-Archiv, (423), 103-108.

Vazhacharickal, P. J., and Jose S. (2016b). Nesting behavior and habitats of the stingless bee Trigona

\section{How to cite this article:}

Prem Jose Vazhacharickal, K. S. Jagadish, G. Eswarappa and Anil, G.B. 2021. Management, Pest and Diseases of Stingless Bee (Trigona iridipennis Smith) with a Special Focus to Kerala, India. Int.J.Curr.Res.Aca.Rev. 9(01), 130. doi: https://doi.org/10.20546/ijcrar.2021.901.001 iridipennis Smith in Kerala: The current status of knowledge. GRIN Verlag, Germany.

Vazhacharickal, P. J., and Jose, S. 2016a. Swarming, drone movements, foraging behavior and associated plants of stingless bees (Trigona iridipennis Smith) in Kerala: An overview. GRIN Verlag, Germany.

Vazhacharickal, P. J., and Jose, S. 2018. Stingless bees culture (Meliponiculture) in Kerala: hand book for farmers. Amazon Publishers, New York, USA.

Vijayakumar, K., and Jayaraj, R. (2013). Infestation of Pyemotes sp.(Acari, Pyemotidae) on Tetragonula iridipennis (Hymenoptera: Meliponinae) colonies. International Journal for Life Sciences and Educational Research, 1(2), 120-122.

Vijayakumar, K., Muthuraman, M., and Jayaraj, R. (2012). Predation of stingless bees (Trigona iridipennis: Apidae, Meliponinae) by centipede (Scolopendra hardwicki: Chilopoda: Scolopendramorpha). International Journal of Advanced Life Sciences, 5(2), 156-159.

Wattena, W. and Jongjitvimol, T. 2007. First record of the predator, Pahabengkakia piliceps Miller, 1941 (Reduviidae, Harpactorinae) in the Stingless Bee, Trigona collina Smith, 1857(Apidae, Meliponinae) in Thailand. Nat. Hist. J. Chulalongkorn univ.7: 7174.

Wille, A. (1983). Biology of the stingless bees. Annual review of Entomology, 28(1), 41-64.

Zulkhairi Amin, F. A., Sabri, S., Ismail, M., Chan, K. W., Ismail, N., Mohd Esa, N. and Zawawi, N. (2020). Probiotic properties of Bacillus strains isolated from stingless bee (Heterotrigona itama) honey collected across Malaysia. International journal of environmental research and public health, 17(1), 278. 